\title{
DO BAD THINGS HAPPEN WHEN WORKS ENTER THE PUblic DOMAIN?: EMPIRICAL TESTS OF COPYRIGHT TERM EXTENSION
}

\author{
Christopher Buccafusco ${ }^{+}$\& Paul J. Heald ${ }^{\dagger \dagger}$
}

\begin{abstract}
According to the current copyright statute, copyrighted works of music, film, and literature will begin to transition into the public domain in 2018. While this will prove a boon for users and creators, it could be disastrous for the owners of these valuable copyrights. Therefore, the next few years will likely witness another round of aggressive lobbying by the film, music, and publishing industries to extend the terms of already-existing works. These industries, and a number of prominent scholars, claim that when works enter the public domain, bad things will happen to them. They worry that works in the public domain will be underused, overused, or tarnished in ways that will undermine the works' economic and cultural value. Although the validity of their assertions turns on empirically testable hypotheses, very little effort has been made to study them.

This Article attempts to fill that gap by studying the market for audiobook recordings of bestselling novels, a multi-million dollar industry. Data from this study, which includes a novel human-subjects experiment, suggest that term-extension proponents' claims about the public domain are suspect. Audiobooks made from public domain bestsellers (1913-22) are significantly more available than those made from copyrighted bestsellers (1923-32). In addition, the experimental evidence suggests that professionally made recordings of public domain and copyrighted books are of similar quality. Finally, while a low quality recording seems to lower a listener's valuation of the underlying work, the data do not suggest any correlation between that valuation and the legal status of the underlying work. Accordingly, this research indicates that the significant costs of additional copyright protection for already-existing works may not be justified. These findings will be relevant to the inevitable congressional and judicial debate over copyright term extension in the next few years.

(C) 2013 Christopher Buccafusco \& Paul J. Heald.

$\dagger$ Assistant Professor, Chicago-Kent College of Law; Co-Director, Center for Empirical Studies of Intellectual Property.

† Professor of Law, University of Illinois, Urbana-Champaign; Professorial Fellow, Centre for Intellectual Property Policy and Management, Bournemouth University (UK). We wish to thank Emily Barney, Steven Benethen, Jessica Bregant, Kacy King, Bin Li, Megan Nolan, Tyler Slack, and Alex Wilgus for their assistance with researching, recording, designing, and analyzing these studies. We are also grateful to the following people for comments on earlier versions of this Article: Richard Watt and participants at the Canterbury University (Christchurch, N.Z.) Department of Economics Workshop; Suzy Frankel and the University of Wellington (Wellington, N.Z.) School of Law colloquium series; participants at the Conference on Empirical Legal Studies; and participants at the annual meeting of the Society for Economic Research on Copyright Issues.
\end{abstract}




\section{TABLE OF CONTENTS}

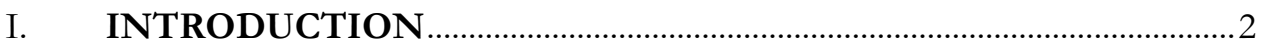

II. THE COPYRIGHT TERM EXTENSION DEBATE ............................6

A. The United StATES: THE 1998 SONNy BONO COPYRIGHT

TERM EXTENSION ACT AND LOOKING AHEAD TO 2018 ......................6

B. INTERNATIONAL LOBBYING EFFORTS..................................................10

C. ECONOMIC JUSTIFICATIONS OF TERM EXTENSION:

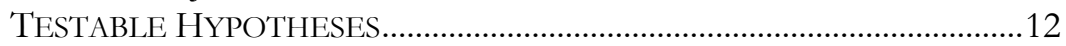

1. The Underuse Hypothesis................................................................13

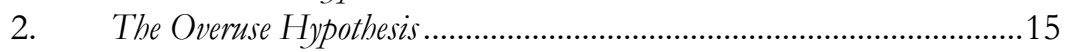

3. The Tarnishment Hypothesis..................................................................16

III. EMPIRICALLY TESTING THE ECONOMIC ASSUMPTIONS: THE CASE OF AUDIOBOOKS ………………..........17
A. EXISTING EMPIRICAL STUDIES OF COPYRIGHT TERM
EXTENSION AND THE PUBLIC DOMAIN ....................................................18
B. STUdy 1: THE EXPLOITATION OF POPULAR FICTION IN

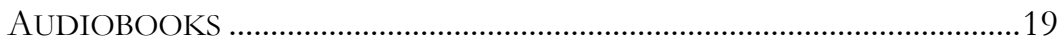

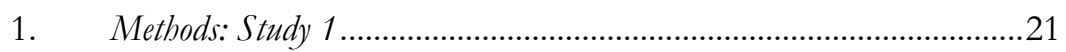

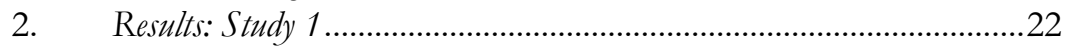
C. STUDY 2: AUDIOBOOK QUALITY AND TARNISHMENT ..........................23

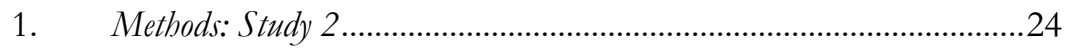

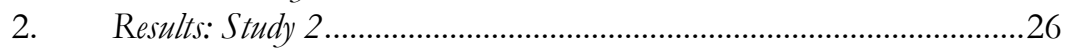

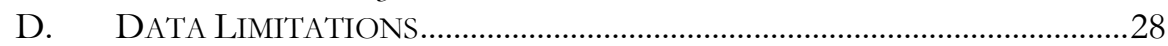

IV. IMPLICATIONS FOR IP LAW AND POLICY: THE NEXT TIME DISNEY COMES KNOCKING _.......................................................29

A. AdDRESSING THE UNDERUSE HYPOTHESIS ...........................................29

B. ADDRESSING THE OVERUSE HYPOTHESIS.................................................

C. ADDRESSING THE TARNISHMENT HYPOTHESIS .......................................33

D. TARNISHMENT BEYOND TERM EXTENSION ...........................................36

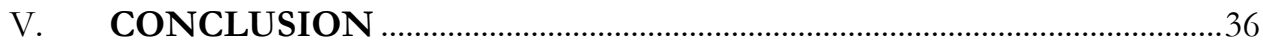

APPENDIX A: FULL SAMPLE OF BESTSELLING

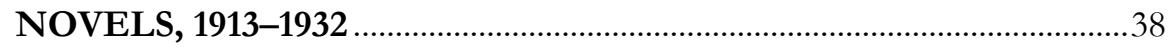

APPENDIX B: DURABLE FICTION BESTSELLERS, 1913-1932.. .43

\section{INTRODUCTION}

In 2018, for the first time in two decades, copyrighted works of art, music, film, and literature are scheduled to enter the public domain. This 
promises to be a huge boon to both the public, who will be able to access these works freely, and to creative artists, who wish to perform, adapt, copy, or otherwise make use of them. Of course, to the owners of some of these copyrighted works, their transition into the public domain means the loss of millions of dollars of revenue. ${ }^{1}$ Book publishers and movie studios will face a world where their creations are available for unauthorized copying and adaptation by anyone. ${ }^{2}$ It seems inevitable that, just as they did in the 1990s, the copyright industries will engage in another round of congressional lobbying to extend the term of protection for an additional period.

The standard justification for intellectual property ("IP") protection is that the exclusive rights of copyright law provide incentives for creators to invest in creating new works. ${ }^{3}$ Theoretically, without IP protection, creators would not be able to recoup the costs of their investment if their creations could be freely copied. The primary argument in favor of extending the copyright term for future works is based on this incentive-to-create rationale: a longer term means that the author will be able to generate more money from her work, thereby increasing the ex ante incentive to create the work in the first place. ${ }^{4}$

The incentive-to-create rationale fails entirely, however, in the case of extending the copyright term for already existing books, music, and movies. The extension of protection for The Sun Also Rises does not increase the incentives for Hemingway to produce more or better work. ${ }^{5} \mathrm{He}$ is, after all, dead. ${ }^{6}$ Accordingly, proponents of term extension have had to offer other

1. The brief for the Petitioners in Eldred $v$. Ashcroft estimated these losses and noted that "because of CTEA [Copyright Term Extension Act], the public will . . . have to pay an additional \$317 million annually in royalties.” Brief for Petitioner, Eldred v. Ashcroft, 537 U.S. 186 (2003) (No. 01-618), 2002 WL 1041928, at*7.

2. Trademark law will provide Disney some relief against unauthorized uses, such as third-party production of a Mickey Mouse doll, that are likely to confuse consumers as to the source of goods or services. See 15 U.S.C. $\int 1125$ (a) (2011).

3. William M. Landes \& Richard A. Posner, Economic Structure of INTELLECTUAL PROPERTY LAW 1 (2003).

4. Id. at 212 .

5. Some argue that a potential author today seeing an extension of Hemingway's copyright will perceive a signal that Congress will give the potential author's works similarly gracious treatment in the future, thereby stimulating the potential author to produce more now. With the present copyright term already at life-of-the-author plus seventy years, the "added incentive" argument has not been taken very seriously. See Lawrence B. Solum, Congress's Power to Promote the Progress of Science: Eldred v. Ashcroft, 36 LOY. L.A. L. REV. 1, 77 (2002).

6. Hemingway Dead of Shotgun Wound; Wife Says He Was Cleaning Weapon, N.Y. Times, July 3, 1961, at 1, available at http://www.nytimes.com/books/99/07/04/specials/ hemingway-obit.html. 
reasons why longer copyrights will increase social welfare. During the adoption of the last copyright term extension legislation and the litigation surrounding it, the copyright industries and some leading scholars asserted three justifications for increasing the term of protection for already existing works. ${ }^{7}$

First, proponents of term extension have argued that, without additional protection, the publishing industries will not have sufficient incentives to preserve, protect, and commercialize old works. They claim that without the protections that copyright provides, works that fall into the public domain will be underused. ${ }^{8}$ This is a version of the classic "public goods" problem in economics that asserts some intangible goods will be under-provided if their producers lack the power to exclude unauthorized users. ' Second, and in some ways the inverse of the first argument, proponents of term extension claim that freely available works will be overused, thereby undermining the works' economic and cultural value. ${ }^{10}$ This is a version of the "tragedy of the commons" (e.g., once anybody can use "Rhapsody in Blue" in a movie or a commercial, the song will be overused and lose its appeal). The proponents' third argument claims that uncontrolled uses of culturally valuable works will tarnish or debase those works, because poorly made or "inappropriate" versions of the works will affect the public's judgments about the works' quality and meaning and therefore their underlying value. ${ }^{12}$ Audiences who see a substandard production of Eugene O'Neill's The Iceman Cometh performed by the Evans Elementary School Drama Club may not wish to read the play or see another performance of it afterward, and thereby never fully grasp the play's treatment of anarchy and socialism. As with the incentive-to-create rationale for new works, these three justifications for extending the term of protection for already existing works have a theoretical appeal. The important question, however, is whether these justifications stand up to empirical scrutiny. This Article attempts to answer that question.

In recent years, legal scholars have turned increasingly to empirical and experimental methods to test longstanding assumptions about how laws operate. These methods have been particularly successful when applied to IP

7. See infra notes $25-31$.

8. See infra notes 25-31.

9. Theodore Groves \& John Ledyard, Optimal Allocation of Public Goods: A Solution to the "Free Rider" Problem, 45 ECONOMETRICA 783 (1977).

10. See infra notes 25-31.

11. See Garrett Hardin, The Tragedy of the Commons, 162 SCI. 1243 (1968).

12. See Justin Hughes, "Recoding" Intellectual Property and Overlooked Audience Interests, 77 TEX. L. REV. 923, 926 (1999) (" $[\mathrm{N}]$ on-owners commonly benefit from owner control that is used to keep a cultural object 'stable." ”). 
law, because, unlike some areas of the law, IP law's assumptions about markets, incentives, and human behavior are explicit. ${ }^{13}$ This Article continues the Authors' previous research applying empirical and experimental methods to IP issues. It reports data from two studies that test the validity of proponents' arguments for extending the copyright term. In short, our study finds almost no evidence to support the claims made in favor of copyright term extension.

Part II describes the debate over copyright term extension and the rationales in favor of it. This Part examines how these rationales affected the last term-extension act and the litigation following it, and how such rationales will likely come up again in renewed calls for extension. Part III reports on empirical tests of the extension rationales. These tests rely on an interesting and understudied creative industry: the market for audiobook recordings of novels. Audiobooks are "derivative works" within the definition of copyright law, ${ }^{14}$ and they present a number of opportunities for studying claims about the exploitation and commercialization of works. Our data compare the markets for audiobook recordings of popular novels on either side of the public domain divide: the decade of public domain works from 1913 to 1922 and the decade of copyrighted works from 1923 to 1932. Part IV applies the empirical findings to the debate about copyright term extension. Although

13. See Christopher Buccafusco \& Christopher Jon Sprigman, The Creativity Effect, 78 U. CHI. L. REV. 31 (2011) [hereinafter Buccafusco \& Sprigman, Creativity Effect]; Christopher Buccafusco \& Christopher Sprigman, V aluing Intellectual Property: An Experiment, 96 CORNELL L. REV. 1 (2010); Deborah R. Gerhardt, Copyright Publication: An Empirical Study, 87 NOTRE Dame L. REV. 135 (2011); Paul J. Heald, Property Rights and the Efficient Exploitation of Copyrighted Works: An Empirical Analysis of Public Domain and Copyrighted Fiction Bestsellers, 92 MinN. L. REV. 1031, 1046-50 (2008) [hereinafter Heald, Fiction Bestsellers]; Paul J. Heald, Does the Song Remain the Same? An Empirical Study of Bestselling Musical Compositions (1913-32) and Their Use in Cinema (1968-2007), 60 CASE. W. RES. L. REV. 1 (2009) [hereinafter Heald, Musical Compositions] (songs are just as likely to be used in films after they fall into the public domain); Paul J. Heald \& Robert Brauneis, The Myth of Buick Aspirin: An Empirical Study of Trademark Dilution by Product and Trade Names, 32 CARDOZO L. REV. 2533 (2011); Raymond Shih Ray Ku et al., Does Copyright Law Promote Creativity? An Empirical Analysis of Copyright's Bounty, 62 VAnD. L. REV. 1669 (2009); Thomas R. Lee et al., An Empirical and Consumer Psychology Analysis of Trademark. Distinctiveness, 41 ARIZ. ST. L.J. 1033 (2009).

14. The Copyright Act defines a derivative work as follows:

[A] work based upon one or more preexisting works, such as a translation, musical arrangement, dramatization, fictionalization, motion picture version, sound recording, art reproduction, abridgment, condensation, or any other form in which a work may be recast, transformed, or adapted. A work consisting of editorial revisions, annotations, elaborations, or other modifications which, as a whole, represent an original work of authorship, is a "derivative work".

17 U.S.C. $\int 101$ (2011). 
this research is in no way conclusive on the issue, it strongly suggests that all three arguments in favor of copyright term extension are mistaken.

\section{THE COPYRIGHT TERM EXTENSION DEBATE}

The primary salience of the data analyzed in Part II relates to the ongoing and vociferous debate over the retroactive extension of copyright protection to existing creative works. Fifteen years ago powerful players in the copyright industries (primarily film, music, and book publishing) lobbied extensively to encourage Congress to pass legislation to prevent their works from falling into the public domain. ${ }^{15}$ Following the success of those efforts in the United States, the copyright industries have pushed for term extensions internationally. ${ }^{16}$ This Part briefly charts the history of the lobbying efforts in both the United States and abroad. It then presents the three primary economic justifications offered in favor of copyright term extension, all of which assert that bad things happen when works fall into the public domain. The data presented in Part III tend to refute the attempts prominent economists and the copyright industries have made to justify extending the term of protection to existing works.

\section{A. The United States: The 1998 SOnNy Bono Copyright Term EXTENSION ACT AND LOOKING AHEAD TO 2018}

The U.S. Constitution provides Congress with the power to "promote the Progress of Science and the Useful Arts, by securing for limited Times to Authors and Inventors the exclusive Right to their respective Writings and Discoveries." ${ }^{\prime 17}$ In 1790, one year after the Constitution went into effect, Congress passed the first copyright statute, providing protection for maps, charts, and books. ${ }^{18}$ This first Act provided authors with a fourteen-year term of protection that could be renewed for an additional fourteen years. ${ }^{19}$ Since the eighteenth century, Congress has extended the copyright term for existing works several times. In 1831, Congress extended the initial term of protection to twenty-eight years with a fourteen-year renewal term, ${ }^{20}$ and the 1909 Copyright Act extended the renewal term to twenty-eight years. ${ }^{21}$

\footnotetext{
15. See infra notes $17-26$.

16. See infra notes 33-40.

17. U.S. CONST. art. I, $\int 8, \mathrm{cl} .8$.

18. See Act of May 31, 1790, ch. 15, 1 Stat. 124 (repealed 1831).

19. Id.

20. See Act of Feb. 3, 1831, ch. 16, 4 Stat. 436 (repealed 1870).

21. See Act of Mar. 4, 1909, ch. 320, 35 Stat. 1075 (repealed 1976).
} 
The last major revision of the copyright statute, the 1976 Act, further lengthened the period of copyright protection. ${ }^{22}$ For existing works that had not yet entered the public domain, the Act added forty-seven years of protection to the twenty-eight-year term resulting in a total of seventy-five years of protection. The Act, which went into effect in 1978, did not retroactively revive copyright protection for works that had already entered the public domain; consequentially, all works published prior to 1923 remain in the public domain. The oldest works still subject to copyright were those published in 1923, and their copyrights were set to expire at the end of 1998. The possibility of these valuable works falling into the public domain seemed disastrous to the copyright owners, who turned to Congress for another extension.

By the time Americans had begun to debate the merits of another copyright term extension, Congress had already passed legislation doing so. The 1998 Sonny Bono Copyright Term Extension Act ("CTEA") added an additional twenty years of protection to the copyright term for all existing works. ${ }^{23}$ Works created between 1923 and 1978 now receive ninety-five years of protection, while works created since 1978 would be protected for the duration of the lives of their authors plus seventy years, with anonymous works, pseudonymous works, and works made for hire receiving a defined ninety-five-year term of protection. ${ }^{24}$

The intense, well-documented lobbying efforts of Disney ${ }^{25}$ and other copyright owners ${ }^{26}$ resulted in the passage by voice vote of the CTEA. ${ }^{27}$ In

22. See Copyright Act of 1976, Pub. L. No. 94-553, 90 Stat. 2541.

23. See Sonny Bono Copyright Term Extension Act, Pub. L. No. 105-298, 112 Stat. 2827 (1998).

24. 17 U.S.C. $\iint 502-304$ (2011).

25. See Bill McAllister, A Capital Way to Stop a Headache, WASH. Post, Oct. 15, 1998, at A21 ("Hill staff members said that other Disney representatives, along with other movie industry representatives, had made strong pleas for a 20 -year extension to all copyrights."), available at http://www.public.asu.edu/ dkarjala/commentary/WashPost10-15-98.html.

26. See John L. Fialka, Songwriters' Heirs Mourn Copyright Loss, WALL ST. J., Oct. 30, 1997, at B1, available at http://news.google.com/newspapers?id=-5NGAAAAIBAJ\&sjid=Dvg MAAAAIBAJ\&dq=songwriters-heirs-mourn-copyright-loss\&pg=5468\%2C3903721.

27. See Keith Pocaro, Private Ordering and Orphan Works: Our Least Worst Hope?, 2010 DukE L. \& TECH. REV. 15, 15 (2010) ("The current state of copyright law, with wildly longer term limits and automatic protection, is a result of continuous content-industry lobbying to protect their valuable, aging intellectual property."); Alan K. Ota, Disney in Washington: The Mouse That Roared, CQ WEEKLY, Aug. 8, 1998, available at http://www.cnn.com/ ALLPOLITICS/1998/08/10/cq/disney.html (describing the Disney lobbying strategy); Dennis Karjala, OpPosing COPYRIgHT ExTEnsion (Jan. 23, 2012), http://homepages.law.asu.edu/ dkarjala/OpposingCopyrightExtension/ (collecting documents related to term extension efforts). 
fact, Disney Chairman Michael Eisner lobbied Senate Majority Leader Trent Lott directly. ${ }^{28}$ The bill sailed through both houses, with eighteen of twentyfive sponsors receiving Disney money, including Lott on the very day he signed up as a co-sponsor. ${ }^{29}$ Opponents to term extension had very little opportunity to participate in discussion of the bill; according to Professor Dennis Karjala:

The hearings [on term extension] were combined with some other bills, so they were not publicized under the bill numbers for those trying to follow the legislation. The proponents of extensionsurprise, surprise! - knew about the House hearings and of course testified in favor. The opponents did not even know the hearings took place until several months later! ${ }^{30}$

With significant royalty streams at stake, ${ }^{31}$ copyright owners and the sponsors of their bill were taking no chances on a full-blown debate over the wisdom of extending the term of protection for valuable works that were about to fall into the public domain.

The failure of Congress to seriously consider arguments that term extension was a hidden tax on consumers, a drag on follow-on creators, and an unconstitutional failure to "promote the Progress of Science" 32 suggests that any rationale offered in the legislative history of CTEA was merely

28. See Disney Lobbying for Term Extension No Mickey Mouse Effort, CHI. TRIB., Oct. 17, 1998 , at 22.

29. See id:; see also William M. LAndes \& Richard A. Posner, The Political ECONOMY OF INTELLECTUAL PROPERTY LAW 16 (2004) (noting that the Center for Responsive Politics showed that in 1996 media interests donated \$1.5 million to six of the sponsors of the Copyright Term Extension Act); John Solomon, Rhapsody in Green, BosTON GLOBE, Jan. 3, 1999, at E2. John Solomon wrote:

Behind the scenes, however, [Disney] has been active. Congressional Quarterly reported that Disney chairman Michael Eisner personally lobbied Senate Majority Leader Trent Lott, a Republican from Mississippi. That day, according to the Center for Responsive Politics, Disney gave Lott a $\$ 1,000$ contribution, following up two weeks later with a $\$ 20,000$ donation to the National Republican Senatorial Committee.

Id.

30. Dennis Karjala, About Copyright Term Extension, OpPOsING COPYRIGHT EXTENSION, http://homepages.law.asu.edu/ dkarjala/OpposingCopyrightExtension/ what.html (last visited Oct. 29, 2012).

31. See Marvin Ammori, The Uneasy Case for Copyright Extension, 16 HARV. J.L. \& TECH. 287, 292 (2002) (noting that Disney in particular stood to lose control of billions of dollars' worth of copyrights-Mickey Mouse and Winnie-the-Pooh alone were valued at nearly $\$ 8$ billion dollars in revenue each-if the CTEA was not passed).

32. U.S. CONST. art. I, $\int 8, \mathrm{cl} .8$. 
make-weight. ${ }^{33}$ Nonetheless, the House Report stated that retroactive extension would "provide copyright owners generally with the incentive to restore older works and further disseminate them to the public." ${ }^{34}$ In the brief debate over the legislation, Representative Howard Coble adopted this rationale and stated that " $[\mathrm{w}]$ hen works are protected by copyright, they attract investors who can exploit the work for profit." 35 Bruce Lehman, former Commissioner of Patents and Trademarks, put the case most strongly in his statement before Congress:

[T] here is ample evidence that shows that once a work falls into the public domain it is neither cheaper nor more widely available than most works protected by copyright. One reason quality copies of public domain works are not widely available may be because publishers will not publish a work that is in the public domain for fear that they will not be able to recoup their investment or earn enough profit. ${ }^{36}$

Whether worries over the lack of availability of older works actually motivated Congress or not, the Supreme Court picked up on the argument in the failed constitutional challenge to the CTEA in Eldred v. Ashoroft. ${ }^{37}$ The Court found that Congress "rationally credited projections that longer terms would encourage copyright holders to invest in ... public distribution of their works." 38 The Eldred litigation forced copyright owners to articulate neutral, public interest rationales to justify retroactively protecting copyrights in existing works. The primary arguments defending term extension enlarged upon the brief statements in the legislative history - that works would be less available to the public if they fell into the public domain.

The lobbying effort for term extension in the late 1990s began as an ordinary — and wildly successful_-plea to Congress to maintain the flow of various copyright-fueled income streams without serious consideration of issues involving the public domain. The debate that peaked in Eldred five

33. See generally Dennis Karjala, Value of the Public Domain, Opposing Copyright EXTENSION, http://homepages.law.asu.edu/ d dkarjala/OpposingCopyrightExtension/public domain.html (last visited Nov. 9, 2012).

34. H.R. REP. NO. 105-452, at 4 (1998). Coble).

35. 144 Cong. ReC. H1458 (daily ed. Mar. 25, 1998) (statement of Rep. Howard

36. Copyright Term, Film Labeling, and Film Preservation Legislation: Hearing on H.R. 989, H.R. 1248, and H.R. 1734 Before the Subcomm. on Courts and Intellectual Property of the H. Comm. on the Judiciary, 104th Cong. 217-18 (1995) (statement of Bruce Lehman, Assistant Secretary of Commerce and Commisioner of Patents and Trademarks).

37. Eldred v. Ashcroft, 537 U.S. 186 (2003).

38. See id. at 207; see also Lawrence B. Solum, The Future of Copyright, 83 TEX. L. REV. 1137, 1165-68 (2005). 
years later had evolved into a full frontal assault on the public domain by copyright owners. In need of a public interest rationale to defend their monetary objectives, rights holders argued that myriad bad things would happen if works were allowed to fall into the public domain, ${ }^{39}$ and thus they asserted term extension was necessary to protect the public interest.

Because the present copyright term extension expires in 2018, Congress will soon decide whether to acquiesce to the next round of lobbying by copyright owners. ${ }^{40}$ In the meantime, other jurisdictions are actively considering U.S.-style term extension. With significant royalty streams at stake in other jurisdictions, the pro-extension lobbying effort has gone global, with mixed success.

\section{B. INTERNATIONAL LOBBYING EFFORTS}

U.S. copyright owners, whose interests are well represented by U.S. trade negotiators, have also poured considerable effort and money into securing term extensions in other countries. These copyright owners have already been successful in imposing term extension on Australia as part of the Australia-U.S. Free Trade Agreement. ${ }^{41}$ Japan $^{42}$ is currently under similarly intense pressure, as are Jamaica ${ }^{43}$ and other developing countries. ${ }^{44}$ The

39. See, e.g., Scott M. Martin, The Mythology of The Public Domain: Exploring The Myths Behind Attacks on the Duration of Copyright Protection, 36 LOY. L.A. L. REV. 253 (2002).

40. Joseph P. Liu has already looked ahead to 2018 in his recent article. See Joseph P. Liu, The New Public Domain (Sept. 12, 2011) (unpublished manuscript), available at http://papers.ssrn.com/sol3/papers.cfm?abstract_id=1926381.

41. See Matthew Rimmer, Robbery Under Arms: Copyright Law and the Australia-United States Free Trade Agreement, 11 FIRST MONDAY, NO. 3 (Mar. 6, 2006), http:/firstmonday.org/htbin/cgiwrap/bin/ojs/index.php/fm/article/view/1316/1236 ("In the trade negotiations, [the U.S. Trade Representative] demanded that Australia ratify the World Intellectual Property Organization (WIPO) Copyright Treaty and Performances and Phonograms Treaty. He supported an extension of the copyright term, so that Australia adopted the standards set by the Sonny Bono Copyright Term Extension Act.") (emphasis removed); see also Maree Sainsbury, Governance and the Process of Law Reform: The Copyright Term Extension in Australia, 9 CANBERRA L. REV. 1 (2006) (detailing lobbying effort in Australia to ratify the Free Trade Agreement).

42. See Mike Masnick, Copyright Extension Moves to Japan, TECHDIRT (Nov. 20, 2009, 7:15 AM), http://www.techdirt.com/articles/20091119/1840217016.shtml; CPB Netherlands Bureau for Economic Policy Analysis, Copyright Protection; Not More But Different (The Hague, Working Paper No. 122, 2000), available at http://www.cpb.nl/en/publication/copyrightprotection-not-more-different (describing an industry "call for additional copyright legislation and enforcement" in the Netherlands).

43. See Mike Masnick, Jamaica the Latest to Embrace Retroactive Term Extension and Screw the Public Domain, TECHDIRT (Oct. 21, 2011, 4:59 AM), http://www.techdirt.com/articles/ 20111014/00471816347/jamaica-latest-to-embrace-retroactive-copyright-term-extensionscrew-public-domain.shtml. 
European Union recently acceded to retroactive extension for sound recordings, ${ }^{45}$ as has Argentina. ${ }^{46}$ A leaked first draft of the proposed Transpacific Partnership between New Zealand, Japan, and Canada would require retroactive extension for all copyrighted works. ${ }^{47}$ But other jurisdictions have not been so easy to convince. Although pressure is constant from the copyright lobby, both the United Kingdom ${ }^{48}$ and Japan ${ }^{49}$ have refused to extend the term of protection for existing works other than sound recordings. One major political party in Brazil has even proposed a reduction in the copyright term. ${ }^{50}$

The United Kingdom seems particularly reluctant to adopt the proposed changes in the absence of supporting empirical data. In fact, the recent government report by Ian Hargreaves urges that

the IP System [be] driven as far as possible by objective evidence. Policy should balance measurable economic objectives against social goals and potential benefits for rights holders against impacts on consumers and other interests. These concerns will be of

44. See Andrew Rens \& Lawrence Lessig, Forever Minus A Day: A Consideration Of Copyright Term Extension In South Africa, 7 S. AFr. J. INFO. \& COMM. 22 (2006); MexicoCopyright Law Amended, LADAS \& PARRY LLP (Mar. 21, 2004), http://www.ladas.com/ BULLETINS/2004/0304Bulletin/Mexico_CopyrightLaw.html.

45. See Martin Kretschmer, Creativity Stifled? A Joined Academic Statement on the Proposed Copyright Term Extension for Sound Recordings, 9 EUR. INTEL. PROP. REV. 314 (2008) (statement of sixty-one law professors opposing extension).

46. Mike Masnick, Here We Go Again: Argentina Extends Copyright, TECHDIRT (Dec. 22, 2009, 5:27 AM), http://www.techdirt.com/articles/20091221/1756577455.shtml.

47. See Michael Geist, TPP Copyright Extension Would Keep Some of Canada's Top Authors Out of Public Domain For Decades, Michael GeisT's Blog (Jan. 9, 2012), http://www.michaelgeist.ca/content/view/6226/125/.

48. See Andrew Gowers, Gowers Review Of Intellectual Property 56-57 (2006), available at http://www.hm-treasury.gov.uk/media/6/E/pbr06_gowers_report_ 755.pdf (study commissioned by the British Treasury department rejecting ex post justifications for extending copyright protection for existing works).

49. See Mike Masnick, Copyright Extension Moves to Japan, TECHDIRT (Nov. 29, 2009, 7:15 AM), http://www.techdirt.com/articles/20091119/1840217016.shtml (reporting on efforts to extend copyright in Japan); Andreas Bovens, Japan to Extend Posthumous Copyright Term to 70 Years?, CHOSAQ, (July 24, 2006), http://chosaq.net/archives/2006/07/japan-to-extendposthumous-copyright-term-to-70-years.html.

50. No National Leeway? Copyright Reform Proposals in Brazil and the Czech Republic, GOVERNANCE ACROSS BORDERS (Sept. 3, 2010) http:/governancexborders.com/2010/09/ 03/no-national-leeway-copyright-reform-proposals-in-brazil-and-the-czech-republic/\#more1095. 
particular importance in assessing future claims to extend rights or in determining desirable limits to rights. ${ }^{51}$

Consistent with the Hargreaves approach, the earlier commissioned Gowers Review of Intellectual Property examined existing empirical evidence and rejected arguments that retroactive term extension was necessary. ${ }^{52}$ Although the United Kingdom had no choice but to accede to the new E.U. directive retroactively extending protection to sound recordings, ${ }^{53}$ the level of skepticism from U.K. officials was significant. ${ }^{54}$

The debate over the economic wisdom of term extension around the world turns on the validity of the same factual assumptions asserted to justify term extension in the United States. ${ }^{55}$ Before explaining how our data bear on the validity of those assumptions, we provide a fuller account of the proextension arguments below.

\section{ECONOMic Justifications of Term Extension: Testable HYPOTHESES}

Jack Valenti, the President of the Motion Picture Association of America, once testified derisively to Congress that public domain works were "orphan[s]," meaning that without parents (owners) they would be subject

51. IAN Hargreaves, Digital Opportunity: A Review of Intellectual PROPERTY AND GROWTH 20 (2011), available at http://www.ipo.gov.uk/ipreviewfinalreport.pdf.

52. See GOWERS, supra note 48 , at 56-57.

53. See Directive 2011/77/EU of the European Parliament and of the Council of 27 September 2011 amending Directive 2006/116/EC on the term of protection of copyright and certain related rights, 2011 O.J. (L 265) 1, available at http://eur-lex.europa.eu/ LexUriServ/LexUriServ.do?uri=OJ:L:2011:265:0001:0005:en:pdf.

54. See Commission Staff Working Document: Impact Assessment on the Legal and Economic Situation of Performers and Record Producers in the European Union, COM (2008) 464 final (Apr. 23, 2008), available at http://ec.europa.eu/internal_market/copyright/docs/term/ia_term_en.pdf (analyzing EU proposal to extend copyright term in sound recordings from fifty to ninetyfive years); Eric Bangeman, U.K. Government Resists Music Industry Pressure, Caps Copyrights at 50 Years, ARS TECHNICA (July 24, 2007, 8:59 AM), http://arstechnica.com/techpolicy/news/2007/07/uk-government-resists-music-industry-pressure-caps-copyrights-at-50years.ars.

55. See Laura Bradford, A Closer Look at the Public Domain, 13 GreEN BAG 343, 344-45 (2010) ("Currently a debate exists globally about the scope of protections for IP.... Proponents of the current strong rules protecting intellectual property argue that a failure to reward innovation curtails investment."); Kretschmer, supra note 45.

56. See Copyright Term, Film Labeling, and Film Preservation Legislation: Hearing on Copyright Term Extension, H.R. 989 Before the Subcomm. on Courts and Intellectual Property of the H. Comm. on the Judiciary, 104th Cong. 55 (1995) (statement of Jack Valenti, President and CEO, Motion Picture Association of America). 
to distressing abuse..$^{57}$ Sophisticated commentators in support of copyright term extension have offered more detailed and theory-driven arguments in support of their position. These arguments fall into three categories: underuse, overuse, and tarnishment. All three primary arguments rely on factual assertions about what happens when works fall into the public domain. Our study of the market for audiobooks, discussed in Part III, infra, tests all three assertions.

\section{The Underuse Hypothesis}

The most prominent justification for term extension asserts that works become less available to consumers when they fall into the public domain. In their influential article arguing for indefinitely renewable copyright for valuable works, law and economics scholars William Landes and Richard Posner reason that "an absence of copyright protection for intangible works may lead to inefficiencies because of impaired incentives to invest in maintaining and exploiting these works." ${ }^{, 58}$ Landes and Posner's argument is a version of the classic "public goods" problem in economics. IP is expensive to create, but once it has been created, it can be cheaply copied and used by others. Because creators of IP cannot easily exclude others from using it, theory implies that they will not be able to recoup their investment costs and will never engage in creating the work in the first place. Thus, the law has to step in to create legal boundaries allowing creators the chance to recover their investments. ${ }^{59}$

This argument can be applied not only to new works but to already created works as well. Some works require costly investments to maintain, produce, and distribute them over time. For example, when audio formats changed, someone had to spend money to transfer recordings on old vinyl disks to a digital format or the old music would not be accessible to most listeners. In theory, because those who would invest resources in the conversion cannot prevent others from free riding on their efforts, they will

57. On the role of metaphors in copyright law, see William PATRY, MORAL PANiCS AND THE COPYRIGHT WARS 44 (2009). Regarding orphan works, Patry writes: "Use of the term 'orphan' inaccurately conjures up an emotional need to protect these works against those who would use them with the copyright owner's permission, even though the 'parents' long ago dropped any interest in them." Id. at 77.

58. William M. Landes \& Richard A. Posner, Indefinitely Renewable Copyright, 70 U. CHI. L. REV. 471, 475 (2003); see also LIOR ZEMER, THE IDEA OF AUTHORSHIP IN COPYRIGHT (2007) (arguing for indefinitely renewable copyright based on five-year renewal terms).

59. Another commentator explains: "If [works enter] the public domain, they [become] obscure and thus no one [will] invest in them due to the problem of free riding. Items which retain enough value for future use should be given indefinite copyrights to maintain their value.” Miriam Bitton, Modernizing Copyright Law, 20 Tex. INTELL. PrOP. L.J. 65, 77 (2011). 
not be able to recoup their investment and, thus, will never bother to invest in the first place. Although this appears not to be the case with digital recordings, ${ }^{60}$ without a method for recouping the cost of conversion, preservation, or reproduction, the underuse hypothesis maintains that commercializers will have inadequate incentives to continue production and distribution of older works. This was the primary worry that Congress expressed when passing CTEA in 1998. ${ }^{61}$

Professor Arthur Miller adds a related concern about the underuse of copyrighted works. He worries that new works deriving from and based on materials in the public domain would be under-produced. ${ }^{62}$ Copyright law gives owners the exclusive right to make or license derivative works like adaptations, sequels, and translations that are based on the original work. ${ }^{63}$ Miller argues that these derivative works will not be made without longer copyright terms. ${ }^{64} \mathrm{He}$ reasons that "you have to provide incentives for [producers] to produce the derivatives, the motion picture, the TV series, the documentary, whatever it may be-perhaps even a musical! ... We must incentivize the dissemination industries, the preservation industries, and the derivative work industries." ${ }^{65}$ According to Miller's argument, without the ability to prevent copiers, no one will be willing to invest the resources in creating a musical version of $A$ Passage to India, because, if it proved successful, others would be able to prepare their own musicals of the book. These competing versions would drive down the value of the first musical, thereby undermining the incentives to create it in the first place. A staunch advocate of term extension, Miller believes that works need owners in order to be adequately exploited in derivative forms. ${ }^{66}$

60. See infra note 85 and accompanying text.

61. See H.R. REP. NO. 105-452, at 4 (1998).

62. Symposium, The Constitutionality of Copyright Term Extension: How Long is Too Long?, 18 CARdozo ARTS \& ENT. L.J. 651, 693 (2000) (panel comments of Arthur Miller).

63. 17 U.S.C. $\int 106(2)(2011)$. at 693.

64. The Constitutionality of Copyright Term Extension: How Long is Too Long?, supra note 62,

65. Id.; cf. Lee Anne Fennell, Common Interest Tragedies, 98 Nw. U. L. REV. 907, 919 (2004) ("The tendency towards overgrazing could thus reinforce one towards underinvestment, leading to a commons featuring too few, and too intensively exploited, intellectual products — at least in the absence of legal rules or norms designed to cabin these tendencies.").

66. See The Constitutionality of Copyright Term Extension: How Long is Too Long?, supra note 62, at 692-94. 


\section{The Overuse Hypothesis}

The "tragedy of the commons," whereby common ownership leads to the degradation of a shared resource, forms the basis of the second primary theoretical justification for copyright term extension. ${ }^{67}$ The tragedy of the commons can occur when a group of people collectively owns some resource, like a pasture. Each person has the incentive to maximize his use of the pasture before others can do so. This leads to overuse and depletion of the pasture through overgrazing. Similarly, if no one has the exclusive right to a creative work, then it might be overused (imagine dozens of advertisers all using the same song). ${ }^{68}$ In such situations, the typical economic solution is to assign individual ownership of the resource so that a single control structure can efficiently manage use. ${ }^{69}$

Landes and Posner make the tragedy of the commons analogy to copyright term extension explicit: "a novel or a movie or a comic book character or a piece of music or a painting" could be depleted like "unlimited drilling from a common pool of oil or gas would deplete the pool prematurely." ${ }^{70}$ Similarly, Stan Liebowitz and Stephan Margolis conclude:

Firms producing copies or derivatives of creative works after the copyright expires may be in the position of fisherman [sic] on an open access lake. They produce at their own private optima, not taking into account the effects that they have on other producers. Ownership can effectively manage these interactions, and copyright provides that ownership. ${ }^{71}$

67. See Hardin, supra note 11.

68. At least one commentator asserts that this was the fate of the classic film It's a Wonderful Life before it was rescued from the public domain. See Scott M. Martin, The Mythology of the Public Domain: Exploring the Myths Behind Attacks on the Duratin of Copyright Protection, 36 LOY. L.A. L. REV. 253, 274-75 (2002). Martin explained:

By the 1980s, there were multiple versions of [It's a Wonderful Life], all in horrid condition. The film was "often sliced and diced by local stations who stuffed it with commercials." There was no quality control over home video copies of the film-consumers had no way of knowing whether the tape they were purchasing was a poor quality bootleg version (which most were).

Id. (citations omitted).

69. See Michael J. Madison, Brett M. Frischmann \& Katherine J. Strandburg, Constructing Commons in the Cultural Environment, 95 CORNELL L. REV. 657 (2010).

70. Landes \& Posner, supra note 58, at 487.

71. Stan J. Liebowitz \& Stephen Margolis, Seventeen Famous Economists Weigh in on Copyright: The Role of Theory, Empirics, and Network Effects, 18 HARV. J.L. \& TECH. 435, 451 (2005). 
In other words, without owners to police the frequency with which a work is used, others may wear it out and reduce its value.

The overuse hypothesis rests on the assumption that the value of creative works, like the value of a pasture, is finite and exhaustible. ${ }^{72}$ Each work has an optimal level at which it should be exploited and each use beyond that level decreases the work's value to others. While an individual owner of the copyright has the incentive to maintain the value of a work over time by preventing it from being overused, once the work falls into the public domain, others will rush to exploit the work's value immediately. ${ }^{73}$ According to this theory a creative work such as a song has increasing social and economic value up to a certain number of uses in a given time period (e.g., in commercials during a year). Once that usage level is met, however, its value diminishes. Individual copyright owners are incentivized to exploit their works at the socially optimal maximum, but if works fall into the public domain, others will overuse the works and diminish their value. ${ }^{74}$

\section{The Tarnishment Hypothesis}

The third rationale for extending copyright protection to already existing works is based on the fear that creative works will lose their value not through overuse but through misuse or tarnishment. A number of commentators have expressed concern that inappropriate uses of works will debase them and reduce their value. ${ }^{75}$ Karjala, a leading opponent of term

72. The overuse hypothesis also assumes that people will exploit the resource in such a way that its value will be diminished. But considerable social science evidence, including from the field of behavioral game theory, demonstrates that this kind of overexploitation does not always take place. See, e.g., Elinor Ostrom, Governing The Commons: The Evolution Of Institutions For Collective Action (James E. Alt \& Douglass C. North eds., 1990).

73. Of course, the assumption that creative works have finite and exhaustible value is itself open to empirical testing and may, in fact, be false. Psychological studies suggest that repeated exposure to things may actually increase their attractiveness. See Robert B. Zajonc, Attitudinal Effects Of Mere Exposure, $9 \mathrm{~J}$. Personality \& Soc. Psychol. Monograph SUPPLEMENT 1, 23 (1968). (1967).

74. See Harold Demsetz, Toward a Theory of Property Rights, 57 Am. ECON. REV. 347, 355

75. See Michael Steven Green, Copyrighting Facts, 78 IND. L.J. 919, 925 (2003). Green argues:

In addition to encouraging authors to create new works, copyrights also encourage authors to efficiently utilize constituents of works that already exist. For example, if no one had a property right in the character Superman, authors could freely create works in which Superman appeared as a character without concern for the effect their works had on the value of actual and potential Superman-based works. 
extension, has coined a phrase to explain what is allegedly lacking when a work falls into the public domain: "proper husbandry by the copyright owner." "T6 The idea behind this hypothesis is that creative works can lose their value not just through overuse but also through the wrong kinds of uses. While the creation of some kinds of derivative works from an original work will be valuable and increase social welfare, other kinds of derivative works will actually decrease the value of the original and harm social welfare.

The most commonly expressed concern here involves the specter of unauthorized pornographic use that dots the literature on the subject. ${ }^{77}$ As Karjala notes, "Rowling, Disney and other creative authors have at least some justification for being outraged when their characters are used in contexts wholly different from the original, such as pornography ..." "78 If viewers see a pornographic poster of Harry Potter, for example, they may tend to dislike and avoid the original movie. Presumably, though, other uses of the original work could harm it through the feedback effects of an audience's reaction to the low quality derivative work as well. As noted above, poor quality productions of plays could undermine people's sense of the value of the drama and its author. Or a poor movie version of a novel might reduce the public's interest in the book. Hence, the asserted need for "proper husbandry," and thus continued ownership of the work.

\section{EMPIRICALLY TESTING THE ECONOMIC ASSUMPTIONS: THE CASE OF AUDIOBOOKS}

Several years ago Professors Liebowitz and Margolis provided an invitation that the present study accepts:

There are, of course, many expensive derivative works that are based upon creations entirely in the public domain. The question is whether they are produced as regularly or as well as they would be

Id.; see also Alex Kozinski, Mickey \& Me, 11 U. MiAmi ENT. \& SPORTS L. REV. 465, 469 (1994) (arguing that unauthorized uses "end up diminishing the value of the product, not just to the creator, but to the general public as well"); Liebowitz \& Margolis, supra note 71, at 449 ("Malicious or offensive derivative uses of some creative works might seriously diminish their value without a sufficient offset in the form of public benefit."). Cf. Hughes, supra note 12, at 926 (arguing that "non-owners commonly benefit from owner control that is used to keep a cultural object 'stable' ").

76. Dennis S. Karjala, Harry Potter, Tanya Grotter, and the Copyright Derivative Work, 38 ARIZ. ST. L.J. 17, 37 (2006).

77. See, e.g., Liebowitz \& Margolis, supra note 71, at 449 n.24 ("The existence of a 'Madeline Does Dallas' might lead to some awkward questions during bedtime stories.'); Heald, Musical Compositions, supra note 13, at 25 ("The entire debate seems to turn on the effect of having unauthorized porn movies starring Mickey Mouse or Superman.”).

78. Karjala, supra note 76 , at 36. 
if they were protected by copyright. ... This is an empirical question to which economists do not yet have the answer. ${ }^{79}$

The Article uses the audiobook market to answer both questions about the quantity and quality of derivative works posed by these two prominent economists.

Audiobooks-audio recordings of fiction and nonfiction books-have become increasingly popular. Originally known as "books on tape," sales of audiobooks have skyrocketed in recent years as technological changes in storage capacity, accessibility, and the ubiquity of smart phones have made listening to recorded versions of books incredibly convenient. The market for audiobooks is estimated to take in $\$ 1$ billion per year, and it is growing at over $10 \%$ per year. ${ }^{80}$ This growth has been led by more than $300 \%$ growth in sales of downloaded audiobooks over a five-year period starting in $2005 .^{81}$ Despite the significance of the audiobook market, no previous research has studied it with an eye towards IP law.

This Part reports two empirical studies of the audiobook market that test the economic assumptions supporting copyright term extension. Study 1 tests the underuse and overuse hypotheses by comparing the availability of audiobook recordings of popular fiction works from the decades on either side of the copyright-public domain divide. Study 2 applies a novel experimental technique to test the misuse hypothesis. Before describing those studies, Section III.A discusses some of the existing research that bears on these questions.

\section{A. EXISTING EMPIRICAL StUdies OF COPYRIGHT TERM EXTENSION AND THE PUBLIC DOMAIN}

One of us has previously tracked the availability of 166 fiction bestsellers from 1913 to 1922 while they were still in copyright and after they fell out of copyright between 1988 and 1997..$^{2}$ Heald measured the percentage of best sellers in print and the average number of publishers per work in a given year and found that, until 2001, public domain books were as available as their copyrighted counterparts. ${ }^{83}$ After 2001, the percentage of in-print public domain bestsellers was significantly higher, as was the number of publishers

79. Liebowitz \& Margolis, supra note 71, at 449.

80. See Industry Data, AUDIO PUBLISHERS Ass’N, http://audiopub.org/resourcesindustry-data.asp (last visited Oct. 15, 2012).

81. Id. The report also notes: "The CD format still represents the largest single source of dollars but showed slight declines overall in 2010 - $58 \%$ of revenue (down from $65 \%$ ) and $43 \%$ of unit sales (down from $46 \%$ )." Id.

82. See Heald, Fiction Bestsellers, supra note 13, at 1039-43.

83. See id. at 1040-41. 
per work. By 2006, 98\% of the public-domain bestsellers from 1913 to 1922 were in print compared to only 74\% of the copyrighted bestsellers from 1923 to $1932 .{ }^{84}$ These data indicate that the fears about underuse may be inflated.

A second study, tracking the use of public domain songs in movies, showed that public domain songs were exploited at a rate equal to that of their copyrighted counterparts. ${ }^{85}$ Heald measured the rate at which songs from 1913 to 1932 appeared in movies and accounted for the number of moviegoers who attended each movie the year of its release. He found no difference in the rates at which moviegoers were exposed to public domain and copyrighted songs. ${ }^{86}$ Also, the study took on the overuse claim directly and found that copyright owners were willing to license their songs for use in movies at an equal or higher rate than public domain songs were used. ${ }^{87}$ In other words, ownership did not function as a relative constraint on comparative use rates in that market.

Finally, at the request of the Library of Congress, Tim Brooks studied the rate at which copyright owners were making old vinyl audio recordings of popular music available to the public. He found that non-owners had converted more music from vinyl to digital format than copyright owners had. $^{88}$

\section{B. Study 1: The Exploitation of Popular Fiction in Audiobooks}

While the research discussed above has cast doubt on the hypotheses offered by some economists and proponents of term extension, the present audiobook studies enable us to more directly ascertain what happens to works when they fall into the public domain. Studying the audiobook market suggests a number of distinct advantages. First, audiobooks constitute derivative works under U.S. copyright law because they are transformations of other copyrighted works. ${ }^{89}$ Many of the arguments concerning term extension discuss the public domain's presumed ill effects on the production of derivative works, so, unlike the research discussed above, this study can

84. Id. at 1040 .

85. See Heald, Musical Compositions, supra note 13, at 10-12 (demonstrating songs in the public domain were used in film once every 3.8 years while songs protected by copyright were used in film once every 3.3 years, with little difference in the relative popularity of films using public domain or copyrighted songs).

86. Id.

87. Id. at $14-15$.

88. See Tim Brooks, Nat'l Recording Pres. Bd., Library of Cong., Survey of REISSUES OF U.S. RECORDINGS 7-8 \& 7 tbl. 4 (2005) (demonstrating that copyright owners have made only an average of 14\% of popular recordings from 1890 to 1964 available on $\mathrm{CD}$, while non-owners have made $22 \%$ of them available to the public on CD).

89. 17 U.S.C. $\int 101$ (2011). 
help explore the public domain's effect on different versions of the same work. Second, derivative works require a capital investment to create, thus studying audiobooks provides an opportunity to measure whether investors are deterred from exploiting public domain works.

The market for audiobooks is distinctive in its heterogeneity. Many audiobooks, of both public domain and copyrighted works, are produced at significant expense by firms that use professional actors working on sound stages. The production and distribution of these audiobooks may cost thousands of dollars per book. ${ }^{90}$ With improvements in computing, however, private individuals may also make their own audiobooks with nothing more than a copy of the book, a computer, and some free software. For example, the website Librivox.org collects, organizes, and distributes thousands of privately recorded audiobooks produced by lay readers. ${ }^{91}$ The site encourages members of the public to submit their own recordings of public domain works; the Librivox staff then reviews the submissions to ensure accuracy and comprehensibility. Librivox, however, makes no effort to judge the quality of recordings or to limit its listings only to those of high quality. ${ }^{92}$ Accordingly, while many of the audiobooks available on its website rival professional recordings in quality, many others are quite poorly made. Study 2 takes advantage of this heterogeneity in audiobook quality to test the hypothesis that low quality derivative works affect the value of the underlying work.

90. Celebrity readers are often paid $\$ 4000$ to $\$ 6000$ for standard six-hour recordings. See Why Celebrities are Lending Their Voices to Audiobooks, PUBLISHING CENTRAL http://publishingcentral.com/articles/20061126-32-06e6.html?si=4 (last visited Nov. 4, 2012).

91. LiBRIVOX, http://www.librivox.org (last visited Nov. 4, 2012).

92. See hugh, Comment to COMPLETE FAQ - Everything You Need to Know (Almost), LibriVox (Nov. 13, 2005, 2:45 PM), https://forum.librivox.org/viewtopic.php?f=18 $\& \mathrm{t}=219 \& \operatorname{sid}=\mathrm{ce} 01 \mathrm{~d} 19 \mathrm{~d} 7 \mathrm{a} 0 \mathrm{c} 0 \mathrm{bf} 3 \mathrm{fc} 0 \mathrm{~d} 2 \mathrm{fb} 30171548 \mathrm{c}$. In response to the frequently asked question, "Don't you have any standards?," user hugh stated:

Our feeling is this: in order for LibriVox to be successful we must welcome anyone who wishes to honour a work of literature by lending their voice to it. Some readers are better than others, and the quality of reading will change from book to book and sometimes from chapter to chapter. But we will not judge your reading, though we may give you some advice if you ask for it. This is not Hollywood, and LibriVox has nothing to do with commercial media's values, production or otherwise. However: we think almost all of our readings are excellent, and we DO try to catch technical problems (like repeated text etc.) with our Listeners Wanted/prooflistening stage. 


\section{Methods: Study 1}

The underuse and overuse hypotheses make empirically testable assertions about the availability of works once they enter the public domain. These hypotheses assert that works will be either under-exploited or diluted, respectively, after they lose copyright protection. Many works subject to copyright, however, have no significant remaining value when they fall into the public domain. Accordingly, the hypotheses are only relevant to those works that have retained significant value at the time when they would enter the public domain. Our study focuses on just these works.

Following the methodology used in one of the studies discussed above, ${ }^{93}$ we derived a list of bestselling novels that were published in the decade before (1913-1922) and the decade after (1923-1932) the copyright-public domain divide (i.e., all of the novels published between 1913 and 1922 have entered the public domain, while all of those published in or after 1923 are still subject to copyright protection). ${ }^{94}$ The list includes 171 public domain novels and 174 copyrighted novels. ${ }^{95}$ Our goal was to collect a sample of fiction from the same period large enough to support statistically meaningful analyses.

Of course, many books that were bestsellers when published may no longer have significant value. Accordingly, we derived a second, smaller list of novels that have shown enduring popularity. This list-generated by examining the number of editions in print and consulting with experts in the literature of the period ${ }^{96}$ - includes twenty public domain novels and twenty copyrighted novels. ${ }^{97}$ These books, like James Joyce's The Portrait of the Artist as a Young Man (1916) and William Faulkner's The Sound and the Fury (1929), are still widely read and retain significant cultural and economic value. This Article refers to these novels as "durable."

To test the underuse and overuse hypotheses, we collected data on the availability and prices of audiobook versions of all 375 works. We searched the most widely used online retailers of audiobooks, Audible.com, ${ }^{98}$

93. See Heald, Fiction Bestsellers, supra note 13.

94. We discarded a handful of post-1922 bestsellers that had not been renewed after the expiration of their initial twenty-eight year copyright term. Such works fell into the public domain and were not eligible for the 1976 or 1998 term extensions.

95. See infra Appendix A.

96. See Heald, Fiction Bestsellers, supra note 13, at 1038-39 (describing the selection methodology for "durable" novels).

97. See infra Appendix B.

98. AudiBLE.COM, www.audible.com (last visited Nov. 4, 2012). Audible.com is owned and operated by Amazon. Id. 
Amazon, ${ }^{99}$ and Barnes and Noble, ${ }^{100}$ all of which sell versions in either CD or downloadable mp3 format. We also cross-referenced our results against the online listing Books in Print, published by Bowker. ${ }^{101}$ In addition to noting the availability of titles, we computed the average prices of professional recordings across the different retailers. Finally, using Librivox, we collected data on the availability of free recordings of public domain novels.

\section{Results: Study 1}

A comparison of the full samples of 171 public domain novels and 174 copyrighted novels shows some similarities and some differences. Of the public domain novels, 58 of the 171 titles $(33 \%)$ have at least one available recording. Of those, 17 only exist in a Librivox recording. There are a total of 193 complete recordings of the recorded works (67 on CD and 126 on mp3), for an average of 3.3 recordings per recorded title. For the 174 copyrighted titles, 27 are available in audiobook format (16\%). Of these, there are a total of 80 complete recordings (44 on CD and 36 on mp3), for an average of 3.0 recordings per recorded title. Interestingly, the average price for the available recordings is fairly similar for public domain and copyrighted titles (Public Domain: $\mathrm{CD}=\$ 26, \mathrm{mp} 3=\$ 22$; Copyrighted: $\mathrm{CD}=\$ 28, \mathrm{mp} 3=\$ 19)$.

Table 1: Full Sample of Novels

\begin{tabular}{|c|c|c|c|c|c|c|c|}
\hline & $\begin{array}{c}\# \text { in } \\
\text { Sample }\end{array}$ & $\begin{array}{c}\# \\
\text { Recorded }\end{array}$ & $\begin{array}{c}\% \\
\text { Recorded }\end{array}$ & $\begin{array}{c}\text { Total } \\
\text { Recordings }\end{array}$ & $\begin{array}{c}\text { Recordings/ } \\
\text { Recorded } \\
\text { Title }\end{array}$ & $\begin{array}{c}\text { Avg. } \\
\text { Price } \\
\text { CD }\end{array}$ & $\begin{array}{c}\text { Avg. } \\
\text { Price } \\
\text { mp3 }\end{array}$ \\
\hline $\begin{array}{c}\text { Public } \\
\text { Domain }\end{array}$ & 171 & 58 & 33 & 193 & 3.3 & $\$ 26$ & $\$ 22$ \\
\hline Copyrighted & 174 & 27 & 16 & 80 & 3.0 & $\$ 28$ & $\$ 19$ \\
\hline
\end{tabular}

For bestselling novels from 1913 to 1932, the data suggest that being in the public domain roughly doubles the likelihood that the work will be available in audiobook format. Despite this increase, however, the fact that a work is in the public domain-and is thus free to be used without licensing-does not ensure that it will be made into an audiobook. Including the versions available on Librivox, fewer than half of the public domain titles are available as audiobooks. Moreover, the similarity in prices between professionally read public domain and copyrighted audiobooks at least suggests that the public domain titles are not being produced in appreciably lower quality versions.

99. AMAZON, www.amazon.com (last visited Nov. 4, 2012).

100. BARNES \& NOBLE, www.bn.com (last visited Nov. 4, 2012).

101. See Bowker, BOOKS IN PRINT, www.booksinprint.com (last visited Nov. 4, 2012). 
For the titles of enduring popularity, the story is similar. All of the twenty public domain titles are currently available in an audiobook version, and there are 6.25 recordings per title. Of the enduringly popular copyrighted works, however, only 17 are currently available in audiobook format (85\%), and there are only 3.25 versions per recorded title. The data on pricing are consistent with Heald's earlier study finding that the 20 copyrighted durable books were significantly more expensive on a price-per-page basis than the 20 public domain durable books. ${ }^{102}$ This study concludes that durable copyrighted audiobooks cost $\$ 0.050$ per minute for CDs and $\$ 0.036$ per minute for mp3 downloads. The corresponding price for the durable public domain audiobooks was significantly lower: $\$ 0.038$ per minute for CDs and $\$ 0.028$ for mp3 downloads.

Table 2: Enduringly Popular Novels

\begin{tabular}{|c|c|c|c|c|c|c|c|}
\hline & $\begin{array}{c}\# \text { in } \\
\text { Sample }\end{array}$ & $\begin{array}{c}\# \\
\text { Recorded }\end{array}$ & $\begin{array}{c}\text { \% } \\
\text { Recorded }\end{array}$ & $\begin{array}{c}\text { Total } \\
\text { Recordings }\end{array}$ & $\begin{array}{c}\text { Recordings/ } \\
\text { Recorded } \\
\text { Title }\end{array}$ & $\begin{array}{c}\text { Avg. } \\
\text { Price/ } \\
\text { min. } \\
\text { CD }\end{array}$ & $\begin{array}{c}\text { Avg. } \\
\text { Price/ } \\
\text { min. } \\
\text { mp3 }\end{array}$ \\
\hline $\begin{array}{c}\text { Public } \\
\text { Domain }\end{array}$ & 20 & 20 & 100 & 134 & 6.25 & $\$ 0.038$ & $\$ 0.028$ \\
\hline Copyrighted & 20 & 16 & 80 & 62 & 3.25 & $\$ 0.050$ & $\$ 0.036$ \\
\hline
\end{tabular}

As with the full sample, being in the public domain increases the likelihood that a work of enduring popularity will be available in audiobook format, and it increases the number of recordings of the title that are likely to be available when compared to similar copyrighted works. For these works, there is full exploitation of public domain novels in audiobook format. Part $\mathrm{IV}$, infra, analyzes whether the number of recordings per title constitutes overexploitation.

\section{Study 2: AudioboOK QuAlity AND TARnishment}

Study 2 addresses the tarnishment hypothesis put forward by economists and proponents of copyright term extension. According to this hypothesis, once works enter the public domain and are free to be used by anyone, the works will be subjected to a variety of inappropriate and poor quality uses that will undermine the works' cultural and economic value. Without copyright ownership, so the argument goes, valuable works will not be properly husbanded. This study focuses only on the durable works described

102. Heald, Fiction Bestsellers, supra note 13, at 1048-49. 
in Study 1. Using a novel experimental methodology, we tested: (1) whether public domain works are produced in poorer quality audiobook versions than are copyrighted works, and (2) whether poorer quality audiobook versions affect the perceived value of the novels from which they are made. ${ }^{103}$

1. Methods: Study 2

To test these questions, we relied on the heterogeneity of available audiobook recordings from multiple sources. As mentioned above, audiobooks are available from both professional and amateur sources. If the tarnishment hypothesis is correct, we would expect that: (1) the quality of audiobook recordings of copyrighted works would be higher than that of audiobooks based on public domain works (because the copyrighted works have an owner to husband them); and (2) the lower quality of the public domain audiobooks would be reflected in a lower perceived value of the underlying novel.

To test these assumptions, we recruited subjects through Amazon Mechanical Turk ${ }^{104}$ to listen to selections of audiobook recordings and to provide feedback on them. After agreeing to participate, the subjects were directed to the survey instrument, hosted on a standard survey platform. ${ }^{105}$ The subjects were told that the survey was being conducted by researchers who were testing the quality of different people as potential audiobook readers. The subjects were then presented with five alternating five-minute recordings taken from the beginning of the fifth chapter of the selected novels. ${ }^{106}$ After listening to each selection, the subjects were asked a series of questions:

1. They were asked two comprehension questions to ensure that they were paying attention.

2. They were asked to rate the quality of the reader's readiness for commercial distribution on a scale of one to six. ${ }^{107}$

103. See supra notes $71-75$ and accompanying text.

104. Amazon Mechanical Turk, WIKIPEDIA.ORG, http://en.wikipedia.org/wiki/Amazon_ Mechanical_Turk (last visited Nov. 9, 2012) ("The Amazon Mechanical Turk (MTurk) is a crowdsourcing Internet marketplace that enables computer programmers (known as Requesters) to coordinate the use of human intelligence to perform tasks that computers are currently unable to do."); see also AMAZON MECHANICAL TURK, https://www.mturk.com/ mturk/welcome (last visited Nov. 9, 2012).

105. QUALTRICS, www.qualtrics.com (last visited Nov. 9, 2012).

106. We selected the fifth chapter to avoid biases associated with particularly wellknown or interesting first chapters.

107. The points on the scale were labeled:

1) This reader could never produce a commercially acceptable audiobook.

2) With great improvement this reader could produce an acceptable audiobook. 
3. They were asked if they had read or seen other versions of the work and, if so, how much they liked them.

4. After being told that the surveyors would have multiple paperback copies of the book left over after completing the survey, they were asked to indicate the price for which the surveyors should sell the extra copies. They were instructed that paperback copies typically sell for $\$ 8$ to $\$ 12 .^{108}$

Finally, after listening to the five different recordings, the subjects were asked a series of questions about their own audiobook usage and demographic background.

We chose the recordings from works on our list of the most enduringly popular novels on either side of the copyright-public domain divide. The sample recordings came from several different sources. Since at the time of the study there were only sixteen professional recordings of the twenty most durable copyrighted works, we selected all sixteen of them. In addition, we randomly selected sixteen of the twenty professionally recorded public domain audiobooks. Comparing the subjects' responses to these sets of recordings enabled us to test whether the professional versions of the public domain works were being produced at the same standards as professional versions of the copyrighted works.

In addition, this study included versions of the works produced by non-professionals. Accordingly, we selected recordings of the same sixteen public domain works that are downloadable on the website Librivox. These recordings had been made by private parties using their own equipment. Of course, because the copyrighted works are still under copyright protection, non-professional recordings of these works are not available publicly. To complete the sample and to provide a control for the comparative attractiveness of the content of all the underlying works, we employed a nonprofessional reader to record copies of the sixteen copyrighted works. This ensured that particularly exciting or interesting prose did not bias the evaluation of the reader.

This strategy gave us a 2 x 2 matrix of recordings (Legal Status: Copyrighted vs. Public Domain; Source: Professional vs. Non-Professional).

3) This reader is close to good enough, but still needs some improvement.

4) The reader was acceptable for commercial distribution.

5) The reader was very good, clearly ready for commercial distribution.

6) The reader was excellent. 


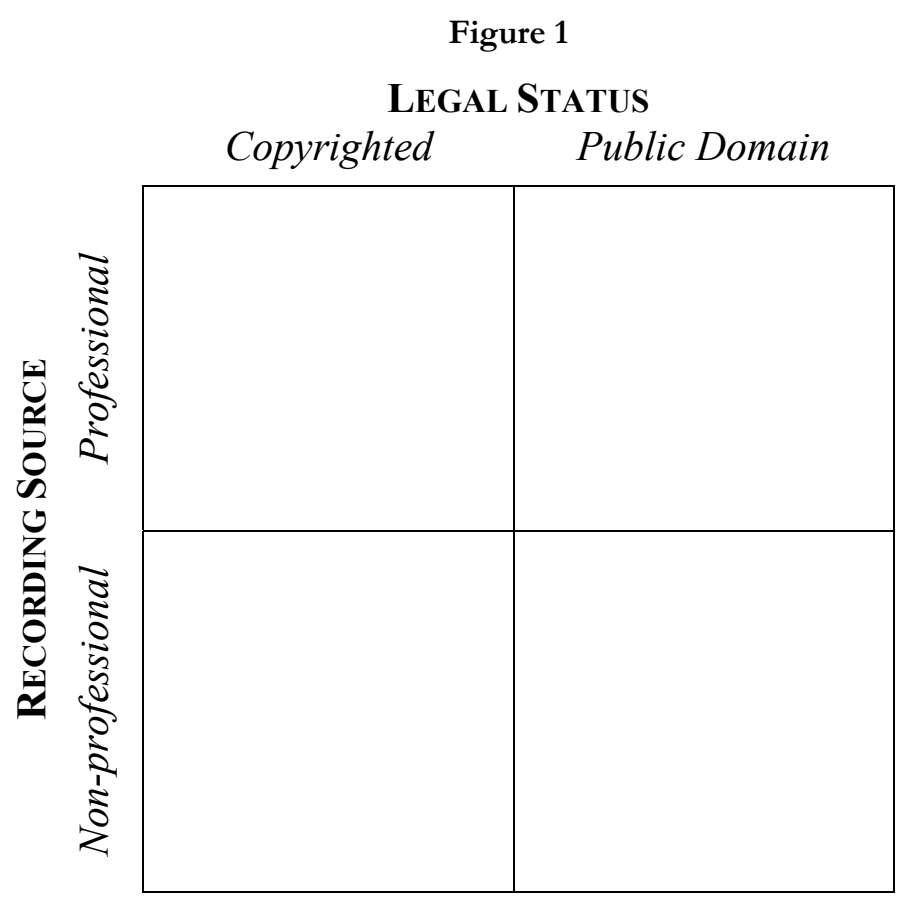

\section{Results: Study 2}

Our data provide almost no support for the arguments made by proponents of copyright term extension that, once works fall into the public domain, the works will be produced in poor quality versions that will undermine their cultural or economic value. ${ }^{109}$ Our data indicate no statistically significant difference, for example, between the listeners' judgments of the quality of professional audiobook readers of copyrighted and public domain texts. ${ }^{110}$ Study 2 also found no significant difference between the recommended prices for which the paperback copies should be sold. ${ }^{111}$ This suggests, as we discuss in more detail below, that the producers

109. In addition to the data reported here, we reran the study with a sample of subjects recruited from the general population by Qualtrics. The results of that study are identical to those reported here, and we chose to report the mTurk data because the quality of the responses that we received were higher in the mTurk sample. The results are available online at http://www.kentlaw.iit.edu/institutes-centers/center-for-empirical-studies-of-intellectualproperty/cesip-projects/copyright-term-extension.

110. Two sample t test, $\mathrm{p}=0.4452$. To indicate a statistically significant difference, the "p value" should be less than 0.05 .

111. Two sample t test, $\mathrm{p}=0.9203$. 
of professional audiobook recordings of public domain works are not using poorer quality readers than are the producers of copyrighted works.

The data do reveal, however, that the amateur recordings of both copyrighted and public domain works are perceived to be of lower quality than are the professional versions. ${ }^{112}$ Librivox recordings of public domain works were perceived to be significantly worse than professional recordings (3.54 versus 4.30 , on a scale of 1 to 6 , respectively), ${ }^{113}$ and the recordings of our assistant were perceived to be significantly worse than professional recordings of both copyrighted and public domain works. ${ }^{114}$ This difference is not surprising - the resources that go into professional recordings will tend to be much greater than those that go into amateur recordings.

The important question, however, is whether the perceived difference in quality between amateur and professional recordings resulted in corresponding value judgments of the underlying work. The answer is a qualified "no," but the data are not entirely unambiguous. In general, we found a positive and statistically significant relationship between the perceived quality of a recording and the amount for which subjects thought copies should be sold. This is important for two reasons. First, it suggests that our metric for studying the underlying value of a work (i.e., asking how much we should sell copies for) is sensitive to changes in quality of the recording and, thus, indicates the validity of the measure. Second, it suggests that people who listen to poor quality recordings of audiobooks are likely to attribute some of their dissatisfaction to the underlying work. Accordingly, there appears to be some feedback effect between the quality of a given version of a work and the value of the underlying work.

Table 3: Quality and Price of Recordings

\begin{tabular}{|l|c|c|}
\hline & Avg. Quality (1-6) & Avg. Price \\
\hline Public Domain Professional & 4.30 & $\$ 8.30$ \\
\hline Copyright Professional & 4.17 & $\$ 8.26$ \\
\hline Public Domain Librivox & 3.54 & $\$ 8.00$ \\
\hline Copyright Research Asst. & 3.56 & $\$ 8.40$ \\
\hline Public Domain Research Asst. & 3.55 & $\$ 7.78$ \\
\hline
\end{tabular}

112. See infra Table 3 .

113. Two sample t test, $\mathrm{p}=0.0002$.

114. Assistant vs. Copyrighted: two sample t test, $\mathrm{p}=0.0027$; Assistant vs. Public Domain: two sample t test, $\mathrm{p}=0.0001$. We detected no significant difference between our assistant's recordings of public domain works and his recordings of copyrighted works. 
Importantly, the correlation between recording quality and price did not manifest itself in the manner predicted by proponents of copyright term extension. The data indicated no statistically significant differences in book price between any of the paired conditions. ${ }^{115}$ Thus, for example, although the Librivox recordings of public domain works were judged to be of lower quality than professional recordings of public domain works, we detected no significant difference between the prices that subjects indicated for the paperback books. ${ }^{116}$ Moreover, although we detected a positive correlation between quality and price for the entire sample of works, we found no such correlation within any of the subsamples. These results suggest that although there may be a modest feedback effect associated with poor quality versions of creative works, that effect is not related to whether a work is protected by copyright or not.

\section{DATA LimitATIONS}

We do not and cannot claim to have established all the precise effects of works falling into the public domain. There may be effects that were not measured or that apply to other industries left unexplored.

One limitation, of course, is that audiobooks are not necessarily representative of copyright-eligible works as a whole. But perhaps the biggest limitation of our data involves the difficulty of scientifically proving the lack of a difference. Social scientific research and statistical methods are normally aimed at demonstrating the existence of a difference between a treatment group and a control group. When such a difference is shown, there is reason to believe that it is the result of true differences between the groups. When no difference is detected, however, the inverse inference is not necessarily true. Failure to find an effect may be the result of an insufficiently sensitive experimental design or inadequate statistical power.

While it is possible that some such problem accounts for our failure to detect a difference between the quality of copyrighted or public domain professional readings, the findings still likely track reality. First, this study included hundreds of subjects sourced via multiple methods, which should have provided the statistical power necessary to detect a difference. Recall, also, that this study detected a significant difference between the quality of Librivox recordings and the quality of professional recordings and a positive correlation between the quality of a recording and the valuation of the

115. In addition, we found no meaningful effects based on prior exposure to the works, although this likely was the result of the small sample of subjects who had prior experience with the works.

116. Two sample t test, $\mathrm{p}=0.3203$. 
underlying work, although that correlation did not map on to differences between the source of the reading (professional vs. Librivox).

Future research should continue to study the effects of the public domain on the value of works. Perhaps other methods can be devised that overcome some of these limitations. In the meantime, however, our data suggest that anxieties about the public domain are substantially overblown.

\section{IMPLICATIONS FOR IP LAW AND POLICY: THE NEXT TIME DISNEY COMES KNOCKING}

Our audiobook study has obvious implications for the ongoing worldwide debate over the extension of copyright terms in existing works. That debate has centered on factual assumptions about what happens to works when they fall into the public domain-assumptions that are contradicted by our data. In addition, our data on audiobook pricing, in conjunction with similar data on book pricing, ${ }^{117}$ illustrate one important reason why the copyright term extension debate should matter to consumers: we found higher prices for recordings of the most popular older works.

\section{A. AdDressing THE UndERUSE Hypothesis}

Lack of availability has been the most prominent concern expressed by Congress and commentators about works falling into the public domain. If works tended to disappear after their copyright terms expired, a plausible argument could be made for term extension because these lost works would be unavailable for future readers, users, and creators. Consistent with several previous studies, ${ }^{118}$ however, we found that audiobooks were significantly more likely to be made from older bestselling public domain works than from bestselling copyrighted works from the same era. Even excluding audiobooks available for free at the Librivox website, the public domain works were more available to consumers in audiobook form. For the full sample, public domain works were twice as likely to be available, and for the sample of enduringly popular works, public domain titles were $20 \%$ more likely to be available. These data suggest that copyright status, in fact, seems to reduce availability, even for the most popular books. Even today, there are no unabridged audio recordings for three of the most popular copyrighted novels in our study: Magnificent Obsession by Lloyd Douglas, Mutiny on the Bounty by Nordoff

117. See Heald, Fiction Bestsellers, supra note 13, at 1048-49; Petra Mosse, et al., Dead Poets' Property - The Copyright Act of 1814 and the Price of Books in the Romantic Period (Nov. 14, 2012) (unpublished manuscript), available at http://papers.ssrn.com/sol3/ papers.cfm?abstract_id=2170447.

118. See supra notes 76-82 and accompanying text. 
and Hall, and Death Comes for the Archbishop by Willa Cather. Further, D.H. Lawrence's Lady Chatterley's Lover (1930) did not appear as an unabridged audiobook until 2011.

The finding that there is a greater availability of audiobooks made from public domain works represents a significant advance over a previous study's finding that bestselling public domain novels are more likely to be in print and in more editions than the bestselling copyrighted novels from the same era. ${ }^{119}$ Unlike reprinted novels, audiobooks are derivative works that require time and effort to produce. Professional versions of audiobooks can cost substantial sums to record, produce, and market; yet, producers do not hesitate to expend significant capital resources to produce their own versions of the work. ${ }^{120}$ Producers of audiobooks are clearly not deterred by their inability to exclude competitors from making competing products. Of 171 public domain titles, 75 had audiobook versions (including 17 Librivox-only versions), while of 173 copyright titles, only 27 had been made into audiobooks. Producers appear more interested in expending capital to produce public domain titles. As our data suggest, the market for public domain audiobooks thrives even though multiple competing versions are often available of the same work. A right to exclude is clearly not needed to incentivize the production of audiobooks made from older works.

If the argument for copyright term extension turns on the need for incentives to reproduce older works or create derivative works from them, then existing empirical evidence suggests that term extensions are not needed and are probably counter-productive.

\section{B. AdDressing THE Overuse Hypothesis}

As discussed in Part II, supra, economists not only worry about the underuse of public domain works, but they also are concerned that some works will be over-exploited if no single owner has the right to exclude others. This tragedy-of-the-commons argument suggests that because no individual has the right to exclude others, everyone has the incentive to rush to exploit the resource while it has value. According to the argument, the public will encounter public domain works so frequently that their value will

119. See Heald, Fiction Bestsellers, supra note 13, at 1046-47.

120. See Liebowitz \& Margolis, supra note 71, at 451 ("Firms producing copies or derivatives of creative works after the copyright expires may be in the position of fisherman on an open access lake. They produce at their own private optima, not taking into account the effects that they have on other producers."). 
be lost. ${ }^{121}$ Our data contradicts this alternative ground for copyright term extension.

For the whole data set, we found an average of 3.3 recordings made for each recorded public domain work and 3.0 recordings for each recorded copyrighted book, an insignificant difference that provides no indication that public domain books are over-exploited and worn out due to their unprotected legal status. In addition, the average price of recorded books in the full public domain data set and the full copyrighted data set was virtually the same, suggesting that the value of the public domain works in comparison to their copyrighted counterparts had not been destroyed by overuse.

This study uncovered no evidence of over-exploitation even when we consider only the most enduringly popular public domain and copyrighted works. In that regard, this study revealed a significant difference in exploitation rates, although the sample size was small. Within their respective groups, the 20 most enduringly popular public domain books had an average 6.25 audiobook recordings per title, while the 16 most popular copyrighted works had only 3.25 audiobook recordings per title. While this is evidence of a higher level of exploitation, further data suggest that there is not evidence of harmful overuse.

One clue that the increased availability of public domain works is not a signal of over-exploitation comes from the pricing data that we accumulated. ${ }^{122}$ Although audiobooks made from the durable public domain works do not command as high a price, the price is still fairly high and close to that for copyrighted works. Even with the competition that professional public domain versions face from free recordings on Librivox, these versions are still able to command market prices that are reasonably close to those obtained by copyrighted works.

While professionally produced public domain audiobooks are priced lower than copyrighted versions, there is little reason to believe that this price difference is due to over-exploitation and the "wearing out" phenomenon. Several compelling explanations for the price difference that are unrelated to an overuse effect also exist. First, the producers of the audio recordings from copyrighted books have to pay a royalty to the copyright owner that may increase the cost of producing the work and raise its price in relation to the public domain works, which require no such payment. Just as likely, the

121. For a succinct expression of this concern in the publicity rights context, see Bitton, supra note 59, at 78 (" $[\mathrm{I}] \mathrm{f}$ everyone uses the likeness of Humphrey Bogart in advertising, it will eventually become worthless.").

122. See supra Table 3. 
"intrabrand" competition between the multiple editions of the audiobooks based on the same public domain work will drive down their prices even in the absence of any "wearing out" phenomenon. Note, however, that despite this competition and the competition from free Librivox recordings, the price for professionally produced public domain audiobooks is still fairly high. Finally, data presented in a prior study suggest a significant disparity in the popularity and appeal of the public domain and copyrighted titles at issue. ${ }^{123}$ If the copyrighted works are indeed more iconic, then we would expect versions of them to be sold at a higher price. Overall, the pricing disparity between audiobooks based on public domain and copyrighted works does not convince us that the public has seen its most valuable public domain works dangerously over-recorded.

In addition, as a practical matter, it is difficult to see how the availability of multiple versions of an audiobook would diminish the value of the underlying work. No one is forced to consume an audiobook, so multiple copies are not flung in the face of the consuming public who then become tired of hearing the story. If audiobooks were played in the background of commercials or department stores, perhaps repetitive, choice-less consumption might negatively affect consumer attitudes, but audiobooks are not used that way. And even with music, which does appear in commercials and in the background ambience of shopping areas, we suspect that businesses try not to alienate their customers by overusing the same music.

123. See Heald, Fiction Bestsellers, supra note 13, at 1046-47. Heald wrote:

[A]s of 1965 , when all of the forty durable books were still protected by copyright, only five of the twenty books (1913-1922) that have since fallen into the public domain had sold 1,000,000 copies. As of the same date, eleven of the twenty books (1923-1932) still protected by copyright today had sold 1,000,000 copies, despite having on the average ten fewer years to accomplish that feat. Even more tellingly, the top five books from the public domain set (1913-1922) had sold a total of only 7,381,709 volumes as of 1965, while the top five sellers from the copyrighted set (1923-1932) had sold 20,289,943 volumes. And as of 1965, the top five books still protected by copyright had fifteen fewer years to sell than those that have since fallen into the public domain. Sales data for books selling fewer than 1,000,000 copies as of 1965 is not publicly available. An update on books that had sold over 2,000,000 volumes by 1975 reemphasizes the comparative popularity of the books published from 1923-1932. Only one of the durable books published from 1913-1922 is on the list (Of Human Bondage, with sales of 2,609,236), while seven from 1923-1932 are on the list. Sales of those seven books, as of 1975, totaled 28,732,714.

Id. (citing Alice Payne Hackett, 70 Years Of Best Sellers, 1895-1965, at 111-45 (1967); Alice Payne Hackett \& James Henry Burke, 80 Years Of Best Sellers, 1895-1975 (1977)). 
Market discipline should make over-exploitation highly unlikely-it is just bad business. It is difficult to imagine how any harm flows from the higher exploitation rate that we measured in the set of the twenty most enduringly popular public domain works.

\section{AdDressing the TARNISHMENT Hypothesis}

Although many legal analysts are skeptical of the claim that "inappropriate" uses of a work can negatively affect its value, ${ }^{124}$ the present study is the first to evaluate empirically the claim that a work will be tarnished by unconstrained uses in the absence of a copyright owner to "husband" the work and protect it from the ravages of the free market. One of us has earlier argued that even pornographic version of works are unlikely to affect value, ${ }^{125}$ but one could imagine, for example, that a truly horrible movie made from a book might have an effect on the sales of the book. If the Howard the Duck comic book had still been regularly in print at the time of the release of its famously awful movie version, ${ }^{126}$ perhaps sales would have dropped (although such a fate would also serve as an example of how copyright ownership does not prevent debasement). By the same token, one could imagine that someone listening to an inferior recording of an audiobook might become less likely to consume the underlying written work, thereby diminishing its value.

Given how easily supporters of copyright term extension can assert the claim of misuse of works in the public domain, it was critical to take the debasement argument seriously. The audiobook context provided an attractive opportunity for study because the claim of tarnishment caused by a poor audiobook reading seems more credible than the claim that Santa Claus

124. See Richard A. Epstein, Liberty versus Property? Cracks in the Foundations of Copyright Law, 42 SAN Diego L. REV. 1, 26 (2005) ("Anyone is hard pressed to believe that Shakespeare's star has been dimmed by the calamities committed in his name ....”); $c f$. Yi Qian, Counterfeiters: Foes or Friends? (NBER Working Paper No. 16785, 2011) (finding that the advertising benefits of counterfeits in the market outweigh any substitution losses); Renée Ann Richardson Gosline, The Real Value of Fakes: Dynamic Symbolic Boundaries in Socially Embedded Consumption (May 5, 2009) (unpublished Ph.D. dissertation, Harvard Business School) (on file with authors) (finding "social networks enable counterfeit consumers to develop relationships with the authentic brand").

125. See Heald, Musical Compositions, supra note 13, at 25-26.

126. See Howard the Duck (film), WIKIPEDIA.ORG, http://en.wikipedia.org/wiki/Howard_ the_Duck_(film) (last visited Nov. 4, 2012) ("The film frequently ranks among the worst films of all time."). 
has been debased by the numerous pornographic movies with "Santa" appearing in the title. ${ }^{127}$

Part II explained that any claim of debasement in the audiobook market would be predicated on two underlying factual assumptions. First, readers of public domain audiobooks are inferior to readers of copyrighted audiobooks; and second, the inferior versions of the audiobooks negatively affect consumers' valuation of the underlying work. We found little support for either assumption.

Regarding the first prong of the tarnishment hypothesis, professional readers of audiobooks made from public domain works were rated just as highly as professional readers of copyrighted books. The companies that produce public domain audiobooks appear to be selecting readers who are as talented as those selected for copyrighted titles. According to the results of our study, when consumers go to the three main sources for audiobooks (www.audible.com, Amazon, and Barnes \& Noble), they will likely find that the public domain books are as well produced as the copyrighted books. These data substantially undermine any claim of debasement in the most important market for audiobooks. Market discipline is apparently sufficient to ensure that the producer of an audiobook for commercial sale will hire a competent reader. Producers of audiobooks would like to establish a positive reputation and make a steady profit in the market. ${ }^{128}$ It should be no surprise that such producers take adequate care in the selection of readers, whether the underlying work chosen for exploitation is copyrighted or in the public domain. Amateur readers who distributed audio versions of public domain books on Librivox were, not surprisingly, rated significantly lower than professional readers of the same books. Non-professionals using their own equipment produce significantly lower quality recordings than professional readers in recording studios.

The question for the second prong of the tarnishment hypothesis, then, is whether these lower quality recordings resulted in lower valuations of the underlying works. Although we did find a positive correlation between the quality of readings and the subjects' valuation of the underlying work, that effect did not correlate with the source of the recording. In other words,

127. See Search Results for "Santa", InTERnet Adult Film DatABASE, www.iafd.com/results.asp?searchtype=title\&searchstring=santa (searching for "Santa" under the title criterion) (last visited May 23, 2012).

128. On the value of attribution and reputation in intellectual property, see Christopher Jon Sprigman, Christopher Buccafusco \& Zachary Burns, Valuing Attribution and Publication in Intellectual Property, 93 BOSTON U. L. REV. (forthcoming 2013), available at http://ssrn.com/abstract=2011403 (finding that creators significantly value opportunities for attribution). 
quality correlates with valuation whether the subject listened to an amateur recording, a professional recording of a public domain book, or a professional recording of a copyrighted book. However, the absolute values assigned to the underlying works by subjects who listened to audiobooks from all three sources were not significantly different. So, the tarnishment thesis has some force, but ownership does not prevent tarnishment in this particular market. Of course, this is contrary to what proponents of term extension argue: that ownership prevents tarnishment in a way that free market discipline does not.

We do not and cannot claim that our data conclusively prove that falling into the public domain has no effect on the value of a work. But even if works are theoretically harmed by falling into the public domain, proponents of term extension should be expected to establish such losses empirically because term extension comes with considerable costs that must be justified. One such cost, already noted, involves pricing. The exclusive rights granted by copyright can sometimes allow owners to charge above-market rates for their products. Imposing such costs on consumers is only worthwhile if the public is getting something valuable in return. Another cost of copyright to consumers is diminished availability. We show that twice as many public domain books have audio versions compared to copyrighted books. If proponents feel that imposing these costs are justified, then they should support their arguments with more than bare assertions.

Perhaps more important than the cost to consumers, other creators must bear higher costs when existing works continue to remain subject to copyright protection. Creators may wish to perform these works, adapt them for new uses, or incorporate them into other kinds of works. ${ }^{129}$ When works are protected by copyright, however, creators must obtain a license or face stiff legal penalties. This license requirement creates multiple problems for new creators and, thus, the public. Copyright owners may demand more in licensing fees than creators are willing or able to pay, resulting in works not getting made. ${ }^{130}$ In other cases, the copyright owners may be impossible to locate and contact. For these "orphan works," the opportunity for bargaining over their use is impossible, and again, derivative works remain uncreated. If the public is going to be asked to bear costs for an additional period of years,

129. See Lawrence Lessig, Free Culture: How Big Media Uses Technology AND THE LAW TO LOCK DOWN CULTURE AND CONTROL CREATIVITY (2004).

130. See Buccafusco \& Sprigman, Creativity Effect, supra note 13 (showing that owners of IP rights often demand substantially more money to license their works than others are willing to pay, leading to inefficiencies in IP markets). 
it is incumbent upon term-extension proponents to establish that those costs are worth bearing.

\section{TARNISHMENT BEYOND TERM EXTENSION}

In addition, our audiobook quality and valuation data may be relevant in multiple contexts outside the copyright-term-extension debate. First, some copyright fair use disputes seem to turn on the argument that inappropriate uses will devalue a copyrighted work. For example, those who oppose the publication of fan fiction (for example, new Harry Potter tales concocted by enthusiastic fans on the internet ${ }^{131}$ ) often allege that the copyrighted characters will be tarnished by unconstrained storytelling on the web. ${ }^{132}$ The data may suggest that amateur fan fiction is unlikely to negatively affect the value of the underlying character franchise.

Second, outside of the realm of copyright law, this study might provide support for those who applaud the judiciary's continuing reluctance to vigorously implement the Federal Trademark Anti-Dilution Act. ${ }^{133}$ The tarnishment prong of dilution doctrine asserts that a trademark loses some of its intrinsic value when consumers encounter the mark used in an inappropriate context, such as when the mark is placed on goods of inferior quality. The data show that listeners to Librivox recordings find the readers to be inferior but do not translate that sentiment to a significantly lower valuation of the associated work. Similarly, the doctrine of post-sale confusion in trademark law rests on the assumption that a trademark owner is harmed when a bystander merely observes a trademark on an inferior product (imagine someone who sees a poor quality Chicago Bears sweat shirt without knowing that it is a knock off). The data suggest that the assumption of such harm is unrealistic and comport with previous studies suggesting that lower quality counterfeits may increase the value of the authentic brand. ${ }^{134}$

\section{CONCLUSION}

The copyright term extension debate, as it once again begins to heat up, will have substantial consequences for the creative industries and the

131. See HARRYPOTTERFANFICTION.COM, http://www.harrypotterfanfiction.com/ (last visited Nov. 4, 2012) (containing over 78,000 Harry Potter stories written by fans).

132. See Karjala, supra note 76; Rebecca Tushnet, Payment in Credit: Copyright Law and Subcultural Creativity, 70 L. \& CONTEMP. PROBS. 135 (2007).

133. See 15 U.S.C. $\int 1125$ (c) (2011) (creating a cause of action against diluting and tarnishing uses of a famous trademark).

134. See Qian, supra note 124 (finding that the advertising benefits of counterfeits in the market outweigh any substitution losses); Gosline, supra note 124, at iii (finding "social networks enable counterfeit consumers to develop relationships with the authentic brand"). 
consuming public. If copyrighted works begin to enter the public domain, their owners will stand to lose millions of dollars in revenue. On the other hand, that revenue comes directly from consumers' pockets, and the expiration of valuable copyrights would save consumers considerable costs. Perhaps more importantly, those works will be available to an army of creative artists who will be able to use them in their works in ways that were impossible while the works were copyrighted. Whether this use will be a good thing if and when it happens is an empirical question that is susceptible to quantitative measurement. This Article has attempted to address that question.

The data suggest that the three principal arguments in favor of copyright term extension-underuse, overuse, and tarnishment-are unsupported. There seems little reason to fear that once works fall into the public domain, their value will be substantially reduced by the amount or manner of their use. Although there may be costs associated with movement into the public domain, allowing open access to public domain works will yield considerable benefits. These benefits should dramatically outweigh the costs. 


\section{APPENDIX A: FULL SAMPLE OF BESTSELLING NOVELS, 1913-1932}

\section{Public Domain Works (1913-1922)}

John Fox, Heart of the Hills (1913); Robert Herrick, His Great Adventure (1913); Jack London, John Barleycorn (1913); Gene Porter, Laddie (1913); Willa Cather, O Pioneers (1913); Eleanor Porter, Pollyanna (1913); O. Henry, Rolling Stones (1913); D.H. Lawrence, Sons and Lovers (1913); Frances Burnett, T. Tembarom (1913); Jeffrey Farnol, The Amateur Gentleman (1913); Winston Churchill, The Inside of the Cup (1913); Rex Beach, The Iron Trail (1913); Gilbert Parker, The Judgment House (1913); W.B. Maxwell, The Devil's Garden (1913); Jack London, The Valley of the Moon (1913); Hall Caine, The Woman Thou Gavest Me (1913); Henry Harrison, V.V.'s Eyes (1913); Ellen Glasgow, Virginia (1913); Robert Herrick, Clark's Field (1914); James Joyce, Dubliners (1914); Leona Dalrymple, Diane of the Green Van (1914); Booth Tarkington, Penrod (1914); Edgar Burroughs, Tarzan of the Apes (1914); Rex Beach, The Auction Block (1914); Harold Wright, The Eyes of the World (1914); William Locke, The Fortunate Youth (1914); George Barr McCutcheon, The Prince of Graustark (1914); Mary Watts, The Rise of Jennie Cushing (1914); Owen Johnson, The Salamander (1914); Frank Norris, Vandover and the Brute (1914); Winston Churchill, A Far Country (1915); Henry Harrison, Angela's Business (1915); Jean Webster, Dear Enemy (1915); F. Hopkinson Smith, Felix O’Day (1915); William Locke, Jaffery (1915); Mary Roberts Rinehart, K (1915); Gene Stratton Porter, Michael O'Halloran (1915); Somerset Maugham, Of Human Bondage (1915); Irving Cobb, Old Judge Priest (1915); Eleanor Porter, Pollyanna Grows Up (1915); Harry Leon Wilson, Ruggles of Red Gap (1915); Dorothy Canfield, The Bent Twig (1915); Theodore Dreiser, The Genius (1915); Stewart White, The Gray Dawn (1915); Ernest Poole, The Harbor (1915); Raphael Sabatini, The Sea-Hawke (1915); Zane Grey, The Lone Star Ranger (1915); Willa Cather, The Song of the Lark (1915); Booth Tarkington, The Turmoil (1915); James Joyce, A Portrait of the Artist (1916); Ethel Dell, Bars of Iron (1916); Peter Bernard Kyne, Cappy Ricks (1916); William McFee, Casuals of the Sea (1916); Eleanor Porter, Just David (1916); Ellen Glasgow, Life and Gabriella (1916); H.G. Wells, Mr. Britling Sees it Through (1916); Frank Spearman, Nan of Music Mountain (1916); Booth Tarkington, Seventeen (1916); Winston Churchill, The Dwelling Place of Light (1916); Kathleen Norris, The Heart of Rachael (1916); William Dean Howells, The Leatherwood God (1916); Henry Kitchell Webster, The Real Adventure (1916); Harold Wright, When a Man's a Man (1916); Edith Wharton, Xingu (1916); Ring Lardner, You Know Me, Al (1916); Alice Cholmondeley, Christine (1917); Edna Ferber, Fanny Herself (1917); Ring 
Lardner, Gullible's Travels (1917); Ernest Poole, His Family (1917); Robert Hichens, In the Wilderness (1917); Christopher Morley, Parnassus on Wheels (1917); David Graham Phillips, Susan Lennox: Her Rise and Fall (1917); James Branch Cabell, The Cream of the Jest (1917); Jeffrey Farnol, The Definite Object (1917); Ethel Dell, The Hundredth Chance (1917); Ralph Connor, The Major (1917); Irving Bacheller, The Light in the Clearing (1917); William Locke, The Red Planet (1917); Stephen McKenna, Sonia (1917); Eleanor Porter, The Road to Understanding (1917); May Sinclair, The Tree of Heaven (1917); Joseph Hergesheimer, The Three Black Pennys (1917); Zane Grey, Wildfire (1917); Gene Porter, A Danghter of the Land (1918); Thorne Smith, Biltmore Oswald (1918); Zona Gale, Birth (1918); Zane Grey, The Desert of Wheat (1918); Edward Streeter, Dere Mable (1918); V. Blasco Ibanez, The Four Horsemen of the Apocalypse (1918); Joseph Hergesheimer, Java Head (1918); Willa Cather, My Antonia (1918); Eleanor Porter, Oh, Money! Oh, Money (1918); Mary Roberts Rinehart, The Amazing Interlude (1918); Booth Tarkington, The Magnificent Ambersons (1918); Emerson Hough, The Passing of the Frontier (1918); E. Phillips Oppenheim, The Pawns Count (1918); Robert Chambers, The Restless Sex (1918); Temple Bailey, The Tin Soldier (1918); Zane Grey, The U.P. Trail (1918); Treat 'Em Rough, Ring Lardner (1918); Margaret Atherton, The Avalanche (1919); Elizabeth von Arnim, Christopher and Columbus (1919); Mary Roberts Rinehart, Dangerous Days (1919); Gene Porter, Dawn (1919); Winston Churchill, Dr. Jonathan (1919); Frannie Hurst, Humoresque (1919); Robert Chambers, In Secret (1919); James Cabell, Jurgen (1919); Albert Terhune, Lad, A Dog (1919); Ethel Dell, The Lamp in the Desert (1919); Joseph Hergesheimer, Linda Condon (1919); Joseph Conrad, The Arrow of Gold (1919); Irving Bachellor, A Man for the Ages (1919); Ellen Glasgow, The Builders (1919); Harold Wright, The Re-Creation of Brian Kent (1919); James Curwood, The River's End (1919); Emerson Hough, The Sagebrusher (1919); Ralph Connor, The Sky Pilot in No Man's Land (1919); Sherwood Anderson, Winesburg, Obio (1919); Edith Wharton, The Age of Innocence (1920); Kathleen Norris, Harriet and the Piper (1920); Peter Kyne, Kindred of the Dust (1920); Sinclair Lewis, Main Street (1920); Eleanor Porter, Mary-Marie (1920); Zona Gale, Miss Lulu Bett (1920); Floyd Dell, Moon Calf (1920); James Huneker, Painted Veils (1920); Sherwood Anderson, Poor White (1920); Mary Roberts Rinehart, A Poor Wise Man (1920); E. Phillips Oppenheim, The Great Impersonation (1920); Zane Grey, The Man of the Forest (1920); Joseph Lincoln, The Portygee (1920); Anne Sedgwick, The Third Window (1920); Francis Fitzgerald, This Side of Paradise (1920); James Curwood, The Valley of Silent Men (1920); Booth Tarkington, Alice Adams (1921); Ben Hecht, Erik Dorn (1921); Harold Bell Wright, Helen of the Old House (1921); Gene Porter, Her Father's Daughter (1921); A.S.M. Hutchinson, If Winter Comes (1921); Brian Donne- 
Byrne, Messer Marco Polo (1921); Rafael Sabatini, Saramouche (1921); Ring Lardner, The Big Town (1921); Dorothy Fisher, The Brimming Cup (1921); Eden Phillpotts, The Grey Room (1921); Coningsby Dawson, The Kingdom Round the Corner (1921); Louis Hemon, Maria Chapdelaine (1921); Zane Grey, The Mysterious Rider (1921); Don Marquis, The Old Soak (1921); Willa Cather, One of Ours (1921); Edith Hull, The Sheik (1921); Gertrude Atherton, The Sisters in Law (1921); Sherwood Anderson, The Triumph of the Egg (1921); John Passos, Three Soldiers (1921); Sinclair Lewis, Babitt (1922); Thomas Stribling, Birthright (1922); Booth Tarkington, Gentle Julia (1922); Carl Vechten, Peter Whiffle (1922); Robert Keable, Simon Called Peter (1922); Francis Fitzgerald, The Beautiful and the Damned (1922); Mary Roberts Rinehart, The Breaking Point (1922); Raphael Sabatini, Captain Blood (1922); Emerson Hough, The Covered Wagon (1922); Temple Bailey, The Dim Lantern (1922); Elizabeth von Arnim, The Enchanted April (1922); Edward Cummings, The Enormous Room (1922); Frances Burnett, The Head of the House of Coombe (1922); A.S.M. Hutchinson, This Freedom (1922); James Joyce, Ulysses (1922); Herbert Quick, Vandermark's Folly (1922); Christopher Morley, Where the Blue Begins (1922).

\section{Copyrighted Works (1923-1932)}

Willa Cather, A Lost Lady (1923); Gertrude Atherton, Black Oxen (1923); Phillip Gibbs, The Heirs Apparent (1923); Arthur Train, His Children's Children (1923); Elliot Paul, Impromptu (1923); Mazo de la Roche, Jalna (1923); John Dos Passos, Streets of Night (1923); Margaret Wilson, The Able McLaughlins (1923); Robert Chambers, The Hijackers (1923); Harold Bell Wright, The Mine with the Iron Door (1923); Zane Grey, The Wanderer of the Wasteland (1923); James Oliver Curwood, A Gentleman of Courage (1924); Margaret Kennedy, The Constant Nymph (1924); Will James, Cowboys, North and South (1924); Michael Arlen, The Green Hat (1924); Clarence Mulford, Hopalong Cassidy Returns (1924); Ernest Hemingway, In Our Time (1924); Emerson Hough, Mother of Gold (1924); Edith Wharton, Old New York (1924); Edna Ferber, So Big (1924); Coningsby Dawson, The Coast of Folly (1924); Louis Bromfield, The Green Bay Tree (1924); Dorothy Fisher (1924); Anne Douglas Sedgwick, The Little French Girl (1924); Booth Tarkington, The Midlander (1924); Percy Marks, The Plastic Age (1924); Robert Herrick, Waste (1924); Theodore Dreiser, An American Tragedy (1925); Sinclair Lewis, Arrowsmith (1925); Ellen Glasgow, Barren Ground (1925); PC Wren, Beau Geste (1924); Sherwood Anderson, Dark Laughter (1925); James Boyd, Drums (1925); Anita Loos, Gentlemen Prefer Blondes (1925); E. Barrington, Glorious Apollo (1925); John Dos Passos, Manhattan Transfer (1925); ASM Hutchinson, One Increasing Purpose (1925); Robert Benchley, Pluck and Luck (1925); DuBose Heyward, Porgy (1925); John Erskine, The Private Life of Helen of Troy (1925); A. Hamilton 
Gibbs, Soundings (1925); Rafael Sabatini, The Carolinian (1925); Francis Scott Fitzgerald, The Great Gatsby (1925); Gene Stratton Porter, The Keeper of the Bees (1925); Gertrude Stein, The Making of Americans (1925); Anne Parrish, The Perennial Bachelor (1925); Willa Cather, The Professor's House (1925); Christopher Morley, Thunder on the Left (1925); Susan Ertz, After Noon (1925); PC Wren, Beau Sabreur (1926); Louis Bromfield, Early Autumn (1926); Dorothy Canfield, Her Son's Wife (1926); Carl Van Vechten, Nigger Heaven (1926); Zona Gale, Preface to a Life (1926); Edna Ferber, Show Boat (1926); William Faulkner, Soldier's Pay (1926); Warwick Deeping, Sorrell and Son (1926); Thomas Stribling, Teeftallow (1926); Temple Bailey, The Blue Window (1926); Sylvia Thompson, The Hounds of Spring (1926); Ellen Glasgow, The Romantic Comedians (1926); John Galsworthy, The Silver Spoon (1926); James Branch Cabell, The Silver Stallion (1926); Ernest Hemingway, The Sun Also Rises (1926); Elizabeth Roberts, The Time of Man (1926); Thorne Smith, Topper (1926); A.A. Milne, Winnie-the-Pooh (1926); Louis Bromfield, A Good Woman (1927); Julia Peterkin, Black April (1927); Conrad Aiken, Blue Voyage (1927); Thornton Wilder, The Bridge of San Luis Rey (1927); Willa Cather, Death Comes for the Archbishop (1927); Warwick Deeping, Doomsday (1927); Sinclair Lewis, Elmer Gantry (1927); Honore Willsie Morrow, Forever Free (1927); Ole Rolvaag, Giants in the Earth (1927); Mary Roberts Rinehart, Lost Ecstasy (1927); James Boyd, Marching On (1927); Ernest Hemingway, Men Without Women (1927); Glenway Westcott, The Grandmothers (1927); Don Marquis, The Lives and Times of Archy Mehitabel (1927); Anne Douglas Sedgwick, The Old Countess (1927); Booth Tarkington, The Plutocrat (1927); Anne Parrish, Tomorrow Morning (1927); Edith Wharton, Twilight Sleep (1927); Fannie Hurst, A President is Born (1928); Anne Parrish, All Kneeling (1928); Vina Delmar, Bad Girl (1928); Booth Tarkington, Claire Ambler (1928); H.W. Freeman, Joseph and his Brethren (1928); Honore Willsie Morrow, Mary Todd Lincoln (1928); Roark Bradford, Ol Man Adam n His Chillun (1928); Warwick Deeping, Old Pybus (1928); Julia Peterkin, Scarlet Sister Mary (1928); John Galsworthy, Swan Song (1928); S.S. Van Dine, The Greene Murder Case (1928); Louis Bromfield Stokes, The Strange Case of Miss Annie Spragg (1928); Hugh Walpole, Wintersmoon (1928); Ernest Hemingway, A Farewell to Arms (1929); Erich Maria Remarque, All Quiet on the Western Front (1929); Anne Douglas Sedgwick, Dark Hester (1929); Sinclair Lewis, Dodsworth (1929); James Thurber, Is Sex Necessary? (1929); Oliver LaFarge, Laughing Boy (1929); Thomas Wolfe, Look Homeward, Angel (1929); Lloyd Douglas, Magnificent Obsession (1929); DuBose Heyward, Mamba's Daughters (1929); O.E. Rolvaag, Peder Victorious (1929); Warwick Deeping, Reaper's Row (1929); Ellen Glasgow, They Stooped to Folly (1929); SS Van Dine, The Bishop Murder Case (1929); Susan Glaspell, The Fugitives Return (1929); Susan Ertz, The Galaxy (1929); Ellery Queen, The Roman Hat Mystery (1929); 
William Faulkner, The Sound and the Fury (1929); Susan Glaspell, Alison's House (1930); J.B. Priestly, Angel Pavement (1930); Kenneth Roberts, Arundel (1930); A. Hamilton Gibbs, Chances (1930); Edna Ferber, Cimarron (1930); Warwick Deeping, Exile (1930); Katherine Anne Porter, Flowering Judas (1930); Vicki Baum, Grand Hotel (1930); Michael Gold, Jews Without Money (1930); D.H. Lawrence, Lady Chatterley's Lover (1930); William McFee, North of Suez (1930); Hugh Walpole, Rogue Herries (1930); John Dos Passos, The $42^{\text {nd }}$ Parallel (1930); Arthur Train, The Adventures of Ephraim Tutt (1930); Mary Roberts Rinehart, The Door (1930); Elizabeth Madox Roberts, The Great Meadow (1930); Dashiell Hammett, The Maltese Falcon (1930); Thornton Wilder, The Woman of Andros (1930); Honore Willsie Morrow, Tiger! Tiger! (1930); Louis Bromfield, TwentyFour Hours (1930); Margaret Ayer Barnes, Years of Grace (1930); Katharine Brush, Young Man of Manhattan (1930); Bess Streeter Aldrich, A White Bird Flying (1931); Susan Glaspell, Ambrose Holt and Family (1931); Fannie Hurst, Back Street (1931); Honore Willsie Morrow, Black Daniel (1931); Mazo de la Roche, Finch's Fortune (1931); William McFee, The Harbourmaster (1931); John Galsworthy, Maid in Waiting (1931); William Faulkner, Sanctuary (1931); Willa Cather, Shadows on the Rock (1931); Warwick Deeping, The Bridge of Desire (1931); Thomas Stribling, The Forge (1931); Pearl Buck The Good Earth (1931); Ernest Hergesheimer, The Limestone Tree (1931); Thorne Smith, The Night Life of the Gods (1931); Erich Maria Remarque, The Road Back (1931); Ole Rolvaag, Their Fathers' God (1931); Sherwood Anderson, Beyond Desire (1932); Aldous Huxley, Brave New World (1932); Julia Peterkin, Bright Skin (1932); Vardis Fisher, In Tragic Life (1932); Phyllis Bentley, Inheritance (1932); Louis Golding, Magnolia Street (1932); Booth Tarkington, Mary's Neck (1932); Charles Barnard Nordoff, Mutiny on the Bounty (1932); Warwick Deeping, Old Wine and New (1932); Pearl Buck, Sons (1932); Phillip Stong, State Fair (1932); Thorne Smith, The Bishop's Jaegers (1932); Robert Herrick, The End of Desire (1932); Charles Morgan, The Fountain (1932); Ellen Glasgow, The Sheltered Life (1932); Thomas Stribling, The Store (1932); AJ Cronin, Three Loves (1932); Erskine Caldwell, Tobacco Road (1932); Sinclair Lewis, Ann Vickers (1933); Hervey Allen, Anthony Adverse (1933); Gladys Carroll, As the Earth Turns (1933); Lloyd Douglas, Forgive us our Trespasses (1933); Erskine Caldwell, God's Little Acre (1933); Caroline Miller, Lamb in his Bosom (1933); Hans Fallada, Little Man, What Now? (1933); Bess Streeter Aldrich, Miss Bishop (1933); William McFee, No Castle in Spain (1933); John Galsworthy, One More River (1933); Robert Herrick, One More Spring (1933); Philip Stong, Stranger's Return (1933); Louis Bromfield, The Farm (1933); Mazo de la Roche, The Master of Jalna (1933); Ernest Hemingway, Winner Take Nothing (1933). 


\section{APPENDIX B: DURABLE FICTION BESTSELLERS, 1913-1932}

\section{Public Domain Durable Works}

Sherwood Anderson, Winesburg, Obio (1919); Edgar Burroughs, Tarzan of the Apes (1914); Willa Cather, My Antonia (1918); Willa Cather, O Pioneers! (1913); Willa Cather, The Song of the Lark (1915); F. Scott Fitzgerald, The Beautiful and the Damned (1922); F. Scott Fitzgerald, This Side of Paradise (1920); Zane Grey, The Lone Star Ranger (1915); James Joyce, A Portrait of the Artist as a Young Man (1916); James Joyce, Dubliners (1914); James Joyce, Ulysses (1922); D.H. Lawrence, Sons and Lovers (1913); Sinclair Lewis, Main Street (1920); Sinclair Lewis, Babbitt (1922); W. Somerset Maugham, Of Human Bondage (1915); Eleanor H. Porter, Pollyanna (1913); Rafael Sabatini, Captain Blood (1922); Rafael Sabatini, Scaramouche (1921); Booth Tarkington, The Magnificent Ambersons (1918); Edith Wharton, The Age of Innocence (1920).

\section{Copyrighted Durable Works}

Pearl S. Buck, The Good Earth (1931); Willa Cather, Death Comes for the Archbishop (1927); John Dos Passos, Manbattan Transfer (1925); Theodore Dreiser, An American Tragedy (1925); William Faulkner, Sanctuary (1931); William Faulkner, The Sound and the Fury (1929); F. Scott Fitzgerald, The Great Gatsby (1925); Dashiell Hammett, The Maltese Falcon (1930); Ernest Hemingway, A Farewell to Arms (1929); Ernest Hemingway, The Sun Also Rises (1926); Aldous Huxley, Brave New World (1932); D.H. Lawrence, Lady Chatterley's Lover (1930); Sinclair Lewis, Arrowsmith (1925); Sinclair Lewis, Elmer Gantry (1927); A.A. Milne, Winnie-The-Poob (1926); Charles Nordhoff, Mutiny on the Bounty (1932); Erich Maria Remarque, All Quiet on the Western Front (1929); Thornton Wilder, The Bridge of San Luis Rey (1927); Thomas Wolfe, Look Homeward, Angel (1929); Percival Christopher Wren, Beau Geste (1925). 
